1922

R 666 . 



\title{
THE EFFECT OF SOME PHYSIOLOGICAL FACTORS ON THE HYDROGEN-ION CONCENTRATION OF THE PLANT JUICE, AND ON THE GROWTH OF CORN SHOWING DIFFERENT DE- GREES OF DISEASE INFECTION
}

\author{
By \\ ANTON ERIC ROMYN \\ B. S. A. University of Toronto 1916 \\ M. S. University of Illinois 1920
}

THESIS

SUBMITTED IN PARTIAL FULFILLMENT OF THE REQUIREMENTS FOR THE DEGREE OF DOCTOR OF PHILOSOPIY IN AGRONOMY IN THE

GRADUATE SCHOOL OF THE UNIVERSITY OF ILLINOIS, 1922 


\section{Digitized by the Internet Archive in 2015}




\section{UNIVERSITY OF ILI,INOIS}

\section{THE GRADUATE SCHOOL}

May $12 \quad-1922$

I HEREBY RECOMINEND THAT THE THESIS PREPARED UNDER MY

SUPERIISION BI Arton Eric ROMyn

ENTITLED The If fect of some Physiologlcal Factors on the Hydrogen-ion Concentration of the Plent Julce, and on the Growth of Com showing Different Degrees of Infection.

BE ACCEPTEI) AS FULFILLING THIS PAR'T OF THE REQITREMENTS FOR 'IHE IDEGREE OF: Doctor of PhIlosophy.

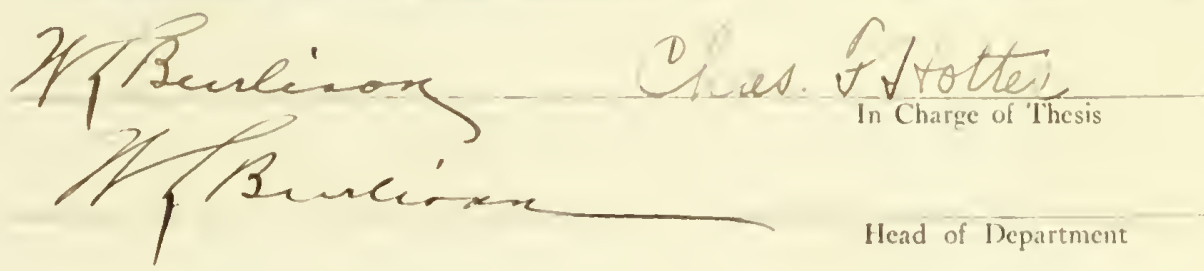

Recommendation concurred in

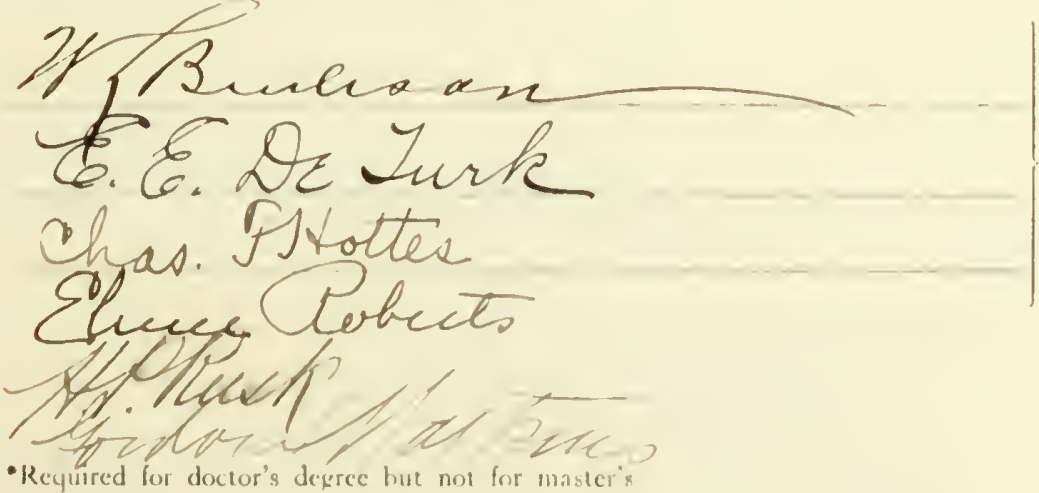

\section{Committee}

on

IFinal Examination* 

A CEGTOWLEDGEVENT

The author wishes to express his approclation of Doctor W. L. Burlison and Doctor C. F. Hottes for their suggestions and help in the diraction of this work. 

CONTENTS

Part I

I

Introduction

II Discussion of procedure and methods.

II Germination tests of seed used.

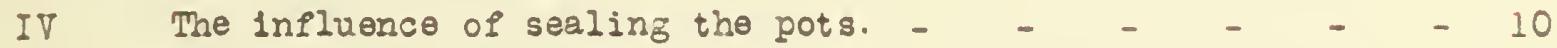

$\checkmark$ The influence of aerat10\%.

VI The nomal varlation of hydrogen-1on concentration in the plant juice.

VII The possible difference in the nutrient requirements of the

diseased and diserse freo plants.

VII The inflience of lining on yield.

IX The Influence of liming on the kidrogen-1 on concentration of the plent jlifco.

X Sumary.

Part II

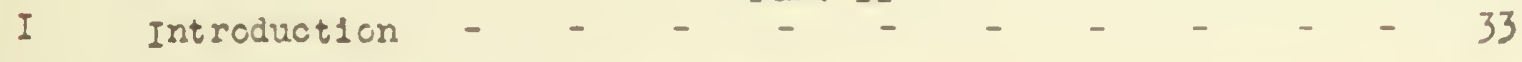

II Discussicn of the raterial and retrods. - - - - - 34

III The infiuence of atmospieric conditions on the hydrogen-1on con-

centration o: the plart jusce. - $\quad$ - $\quad$ - $\quad$ - -38

IV The Influence of age on the hydrogen-1on concentration of the

plant julce.

V A cariparison of the hydrogen-1on concentration of the plart juice

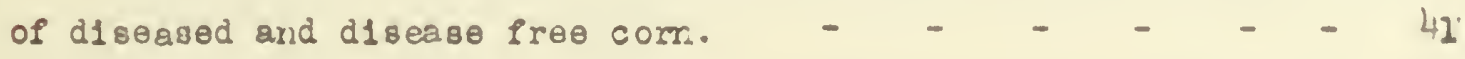

VI The influence of lining on the hydrogen-1on concentration of the

plant julce.

VII The Influence of disease on the hydrogen-icn concentration of the plant jusce. 



\section{INTRODUCTION}

A number of workers have noticed a relation between the hydrogen-1 an concentration of the plant juice and the reacticn of certain plents to tho attack of fungous diseases.

Barvey, for instance, working with beet and riclnus found the hydrogen-ion concentration less in the diseased areas than in the surrounding kealthy t1ssue. Freeman Fe1ss and Harvey $3^{\circ}$, on the other hand, working with poteto wart d1scovered that the hydrogen-1on concentrat1cn was constantly greater in the warts.than in the norral t1ssue. Wager ${ }^{28}$, after irjecting Fathogenic orcenisms into a variety of succulent plants, was able to show that there was an 1ncrease 1n the ac1dity of the julce. Thlo increase was followed elther by a return to normal or by a rapld decrease in acidity and death. Lately Hofferll has reported that the hydrogen-1on concentrat1cn of the julce of the lower nodes of diseased com plants 18 markedly less then that of disease free plents.

The acldity of the plant julce undoubtedly plays a very inportant physiological role ir the developuent of the plant. It is hardly the province of this article, bowever, to go irto a full discussion of this phase of the subject. It has been maintained that such functions as the percieability of the cell mexbranes, the rate of enzymat1c raacticns, the osmotic properties of the cell sap and the solvent powers of the plant julces are largely influenced by the reaction of the sap. And, whlle the findinge reported in the previous paragraph are not consistent, they all sean to show thet the entrance of pathogenic organisnis into the plant tissue produces, elther directly of 1ndirectly, some slgniflcant change in the reaction of the juice. It is laportant to find out 1 these changes can be checked by 

any external means and if certain pH values are associated with imunity to disease attack. With positive information on either of these points, we may be able to discover some way of prevent1rg the inrcads of the pathogenes, eltber by providing a suftable environient, or by some system of genetic selection.

The first thing to determine, however, is whether such changes do occur In the corn plant and, if so, if they can be influenced by extemal conditions. It wes witb this idea in mind that the following experinents were planned. Dent corn (zea mays indentata), infected with both Fusarium moniliom and Diplodia zeae, was chosen as the material to work on. It 1s estimated that the annual dariage caused by these diseases in the United States is about five percent of the totel crop. The economic irportance of any method for their control can therefore be easily rocognized. 



\section{MATERIAIS}

Seed The corn in this experiment was a strain of Reld's Yellow Dent, grow at Bloomington, Illino1s. Unfortunately neither the diseased nor the disease free strain was entirely diseased or disease free. There were some disease free bernels $1 \mathrm{n}$ the diseased strain and some diseased seed in tho disease free strain. There was, however, sufflclent difference in the amount of disease infection to matie the results obtained in this investigation reasonably conclusivo.

Sand The quartz sand (flint silica) used was obtaired from the United States S1I1ca Company, Chicago. Its saturation coefflcient when measured by 9 the Hilgard shall cw cup method was twenty-three percent. As only comparative results were almed at in this experiment, it was not thought necessery to wash the sand befcre use.

Chemicals In the preparation of the nutrient solutions, the methods outlined in the Bulletin of the National Research Councli on "A. Plen for Cooperative Research on Salt Requirements" 19 were closelj followed. Bakrer's chemicals and Sbive's optimum $\mathrm{B}_{5} \mathrm{C}_{2}$ solution were used in all the experiments. A departure was made irs the case of 1ron. Thls element, as recamended in 8 ane later work of Jones and $\mathrm{Shive}^{14}$, was added as FeSO4 at the rate of .075 m.grm of 1ron per liter of sol. $\mathrm{CaCO}_{3}$, screened down to particles between 1-1.5 In size, was added as commercial limestone. One gram per kllo was carefully mixed with the sand. Taking the wolght of the surface $62 / 3$ " of 8011 as 2,000,000 pounds, this quantity corresponds to one ton per acre.

Pots Glass butter jars, holding about 1500 grns of dry send each, were used as contalners. They were surrounded by stiff poper to exclude the light. Hydrogen-1 on Apperatus Hydrogen-ion detemsinations were made by the hydrogen electrode. The apparatus used consisted essent1aliy of (plate 1): 



\section{4-}

a Leeds Northrup Potenticreter, Leeds Northrup Gelvonameter, type H, a $\mathrm{n} / 10$ calanel all made up according to Clark'sé directions, a small cell modelled on the one devised by Haas6, and a Palladiun coated Platinum wire forming the hydrogen electrode. Compressed hydrogen, obtained from the Universal oxygen Company, Shoyboygan, Wisconsin, and passed through alkaline pyrogallate and distilled water before reaching the electrode, was used as the source of bydrogen. 



\section{$-5-$}

IIETHODS

Preparation of the pots The directions given by the National Research Counc11 19 were cons1derably departed from in setting up the pots. These were kept at sixty percent of saturation. This amount of molsture was found to Give the best results in sace preliminary trials. It is worth noting here that these tests, which were carried out in sumer at a temperature of $32^{\circ}$ $37^{\circ} \mathrm{C}$, seem to show that the percentage of water in the disease free pots can be reduced to forty percent without mariedly effecting the yleld, but that a decrease to forty percent in tio diseased pots brings about a distinct decrease in growth.

The sand was made up to the required molsture in a large mixins bowl and tzen shaken dom uniformly into the different pots, while a glass tube, closed at lower end by a strainer made of a double thickness of cheese cloth, was held in position ageinst the side of the pot unt1l all the sand had been firmly sbaken down.

Three kernels of com per pot were then planted In below the surface of the soll and tie pots sealed. Tho seal used consisted of fifteen percent vaseline and eighty-five percent parawax. At the laboratory temperature, the plants seemed to experience no difficulty in piercing this seal, which was poured on eufficiently warm to spread evenly.

Renewel of Solution The method of renewing the solution varied in the different experiments. The sand in each pot contalned about $210 \mathrm{cc}$ of nutrient solution. Thls was usually changed twice a week. At the end of each three and one-half day period each pot was welghed and sufflcient dist1lled water added through the cone to replace the nolsture lost. All the easily removable water was then drawn off by an aspirator and $50 \mathrm{cc}$ of fresh solution was. added. Aftor this nearly all the free molsture was agaln drawn off and the 



\section{$-6-$}

pots were made up to wight with fresh solution. This method required the addition of 100-120cc of solution at each aeration. In the earlier experinents no attempt was maje to secure equal quantities of aeration when the solution vas changed, but in experiments 11-12-13 this was secured by a device wizich will be described later.

Losses in transpiration were made up by the dally addition of distilled water.

Treatment of Pots Those were placed on a rotating table (plate 2) which was kept in operation from 8 a.m. to $5 \mathrm{p.m}$. The temperature of the green house was maintalned at $20-25^{\circ} \mathrm{C}$ and watered twice a day to keep the atmosphere mo1st.

\section{Determinat1ors Determinations were made as soon as possible after} harvest1rig the plants. In no case was the period botween harvest and the hydrogen-ion deternination longer than two hours. During the interum, the plants were kept in a vasculum and the julce was tested inmediately on extract1on.

The tops were not washed, but the roots in each case were washed f1rst in tap water then in distilled and finally dried on fllter paper. The remains of the kemels were then cut off and the plants weiched.

The tops or roots of the three plants were ground up together in a porcelain mortar and the pulp collected on a small clean square of cheese cloth. Th1s was squeezed out between two strips of stiff paper in a vice. The juice (each sanple being the compcsite of three plents) was then tested without further treatment.

Readings were made in duplicate and the apparatus checked from time to t1me against a m/20IKPhthalate solution of known hydrogen-1 on concentration.

A Presh electrode was used in each set of experimerts. The capllis.ry 



\section{$-7-$}

tube at the end of the KC' bridge was very finely drawn out so as to limit the diffusion of the salt into the plant juice. After maling the necessary temperature corrections, Schmidt and Eoagland's 23 tables were used for converting observed roltages to pH.

It may be well to point out here that, while the methods of extraction were of necessity rather rough, this disadvantage applied equally to the disessed and disease free corn and so did not interfere greatly with the comparative vaiue of the results. 

Briefly, the object of the following experiments was to determine the difference in the hydrogen-icn concentration of the fuice of diseased and disense free plants and the effect of several external factors on this acidity.

This could not be dori, however, until the influence of several physical and physiologlcal factors such as (a) Kind of seed, (b) Effect of sealing the pots, (c) Effect of variation ir the amount of aeration, (d) The naturel amount of variation in hydrogen-ion concentration to be expected in the juice of normal plents, had been first worled out. The first series of tests to be described were therefore planned to obtain data along these Iines.

\section{Gerrination Tests of the Seed Used}

The seed used has already been described. Unfortungtely it was not altogether elther diseased or disease free as the case might be. Three tests were run using a total of one nundred kemels to deterine the amount of disease irfection.

The seed was gerringted on Plaster of Parls blocks kept in a flat calvanized 1ron gerrinating pan with a close fitting lid. Both the pan and the ulocis were bollod for thirty cinutes before the seeds were placed on the blocks. As a result of this precaution, vory little surface mold appeared on the blocks carrying disease fres seed, though there was soine growth of Rhizopus on the diseased blocks. The seedlings wore grown for ten days at roam tsmperature and then a disease count made by sectioning the kemels. All kernels showing discolored embryos were arbitrarlly counted as diseased. The results are given in Table 1 . 



\section{Ceruination Record of ths Two Strains}

Table 1.

\begin{tabular}{|c|c|c|c|c|c|c|c|c|}
\hline \multirow{2}{*}{$\frac{\text { Experiment }}{1}$} & \multicolumn{2}{|c|}{ Namber of Seeds } & \multicolumn{2}{|c|}{$\begin{array}{l}\text { Number } \\
\text { Gerinating }\end{array}$} & \multicolumn{2}{|c|}{$\begin{array}{c}\text { Length of } \\
\text { Shoot }\end{array}$} & \multicolumn{2}{|c|}{$\begin{array}{c}\text { Number of diseased } \\
\text { plants in }\end{array}$} \\
\hline & $\begin{array}{c}\text { D. } \\
25\end{array}$ & 25 & $\frac{D . F}{25}$ & $\begin{array}{l}\text { D. } \\
24\end{array}$ & $\begin{array}{l}\text { D.F. } \\
12 \mathrm{c}:\end{array}$ & $15 \mathrm{~cm}$ & $\begin{array}{c}\text { D. F. } \\
7\end{array}$ & D. \\
\hline 2 & 50 & 50 & 50 & 49 & 11 & 15 & 11 & 39 \\
\hline 3 & 25 & 25 & 25 & 25 & 11 & 13 & 6 & 18 \\
\hline Total & 100 & 100 & 100 & 38 & 11.3 & 14.3 & 24 & 75 \\
\hline
\end{tabular}

It is insodiately apparent that the diseage freo strain contained many (twenty-four percent) apparently diseasod kernels. The only aljnificant difference that appears betreen the two is that the disoased strain contalns about three times as many kemels showing scutellun rot as the disezse free. This proportion appears in all three trials.

Valleau 27 reported the sace difflcalty in socuring entiraly disease free seed, but he wes able to dexonstrate that the anount of infection show in the original test was an indication of the final perfornance of the seed when grown to maturity. Sorne data in process of publication obtalned by J. R. Holbert, in cooperation with the Illinols Experinent Stationl? show a similar close correlation between early vigor and subsequent yield. Scitellum discoloration on the germinator is not necessarily due to corn root and stalk pethogenes. It may be due to Rhlzopus and other external infection. But, on the basis of Valleau's work and that of the Illinols Experiment Station fust quoted, the two stralns of corn used soem to show sufficient differences in vigor and in resistanco to the development of disease to meet the requirments of this experiment. For the sake of convenlence, the tercs "dlsease free" and "dlseased" have beon adhered to in 

the write up of this work. Although they do not accurately describe the status of the seed, they give a fair comparative description of the material worked vith.

\section{Effect of the Seal}

Four pots were left unsealed in each of experinents 11-12-13. These unsealed pots were covered by inverted glass jars until the young shoots were through the soll, after wich the jars were removed and the moisture content of the pots rept nearly constant by the addition of distilled water twice a day. The nutrient solution in these pots was changed in the ordinary way. Tables 2 and 3 give the results of those experiunents.

\section{Efrect of Sealing the Pots on Yield}

Table 2.

\begin{tabular}{|c|c|c|c|c|c|c|c|c|}
\hline \multirow[t]{3}{*}{ Bxperiment } & \multicolumn{4}{|c|}{ Disezse Free } & \multicolumn{4}{|c|}{ D1sersed } \\
\hline & \multicolumn{2}{|c|}{ Tops } & \multicolumn{2}{|c|}{ Roots } & \multicolumn{2}{|l|}{ Toos } & \multicolumn{2}{|c|}{ Roots } \\
\hline & Segl & No Seal & Seal & No Seal & Seal & No seal & Seal & No Seal \\
\hline 120 & $2.958 \mathrm{rdh}$ & 6.20 grax & $2.47 \mathrm{grm}$ & $4.698 \mathrm{~mm}$ & $3.058 \mathrm{rm}$ & $3.70 \mathrm{gr}$ & 2.86 गुत्व & 2.470 \\
\hline 12 & 4.62 & 5.15 & 3.38 & 3.70 & 2.69 & 2.00 & 1.78 & .98 \\
\hline 13 & 3.09 & $5 \cdot 30$ & 2.42 & 3.68 & 2.73 & 3.17 & 1.79 & 2.28 \\
\hline Averge & 3.55 & 5.55 & 2.76 & 4.09 & 2.82 & 2.96 & 2.14 & 1.91 \\
\hline 11 & 5.60 & 3.92 & 4.20 & 3.47 & 2.30 & 3.46 & 1.78 & 3.70 \\
\hline 12 & 6.21 & $5.5 \overline{5}$ & 3.58 & 3.93 & 2.36 & 5.15 & 1.36 & 3.70 \\
\hline $13^{\mapsto}$ & 4.56 & 5.49 & 3.30 & 3.62 & 3.54 & 2.00 & 2.75 & 1.70 \\
\hline Averaze & 5.46 & 4.99 & 3.69 & 3.67 & 2.73 & 3.54 & 1.96 & 3.03 \\
\hline
\end{tabular}



Ffect of Sealing the Pots on Eydrozen-ion Concentration

Tabio 3 .

\begin{tabular}{|c|c|c|c|c|c|c|c|c|}
\hline \multirow{3}{*}{$\begin{array}{l}\text { Exper - } \\
\text { Iment }\end{array}$} & \multicolumn{4}{|c|}{ Disease Free } & \multicolumn{4}{|c|}{ Disensed } \\
\hline & \multicolumn{2}{|c|}{ Tops } & \multicolumn{2}{|c|}{ Root 8} & \multicolumn{2}{|c|}{ Tops } & \multicolumn{2}{|r|}{ Roots } \\
\hline & $\begin{array}{l}\text { Seal } \\
\text { 묘 }\end{array}$ & $\begin{array}{c}\text { No seal } \\
\mathrm{pH}\end{array}$ & $\begin{array}{c}\text { Soal } \\
\mathrm{pH}\end{array}$ & $\begin{array}{c}\text { No seal } \\
\mathrm{pH}\end{array}$ & $\begin{array}{c}\text { Ssal } \\
\text { pH }\end{array}$ & $\begin{array}{c}\text { No sesl } \\
\mathrm{pH}\end{array}$ & $\begin{array}{c}\text { Seal } \\
\mathrm{pH}\end{array}$ & $\begin{array}{c}\text { No sea } \\
\text { pd }\end{array}$ \\
\hline 11 & 5.553 & 5.596 & 5.883 & 5.731 & $5 \cdot 545$ & 5.511 & 6.061 & 5.883 \\
\hline 12 营 & 5.646 & $5 \cdot 579$ & $5 \cdot 976$ & 5.985 & 5.604 & 5.596 & $5 \cdot 968$ & - \\
\hline $13:$ & 5.460 & $5 \cdot 342$ & $5 \cdot 790$ & 5.714 & 5.503 & $5 \cdot 528$ & 5.933 & 5.866 \\
\hline Average & 5.553 & 5.506 & 5.833 & $5 \cdot 8^{\prime}+3$ & 5.531 & $5 \cdot 545$ & $5 \cdot 987$ & 5.874 \\
\hline 11 & $5 \cdot 503$ & $5 \cdot 562$ & $5 \cdot 790$ & $5 \cdot 731$ & 5.579 & $5 \cdot 511$ & $5 \cdot 900$ & 5.883 \\
\hline 12 : & $5 \cdot 562$ & $5 \cdot 545$ & 5.832 & $5 \cdot 900$ & 5.587 & $5 \cdot 511$ & 5.942 & 5.850 \\
\hline 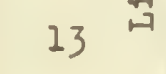 & 5.426 & 5.461 & 5.798 & 5.765 & 5.410 & $5 \cdot 528$ & 5.900 & 5.366 \\
\hline Avergge & 5.497 & $5 \cdot 523$ & 5.807 & 5.799 & 5.525 & 5.517 & $5 \cdot 914$ & 5.866 \\
\hline
\end{tabular}

These results show that the seal had an unfevorable effect on the plants. In all the unlimed pots it reduced the total yisld with the exception of the diseased pot in experiment 12, where the total yleld was higher In the sealed pot. In this latter case, however, the plants in the unssaled pot happened to be so badly diseased that the effect of the disease pathogenes turned out to be greater than that of the seal.

In the Ilroed pots the harnful effect of the seal on the disease froe plants was apparently largely overcome by the addition of $\mathrm{CaCO}_{3}$, but the damage was not decreased in the case of the diseased plants. As will be brought out later, the roason for this was due to the fact that sealing the 

pots apparently greatly increased the effects of disease. So what was measured here was not roally a decrease in the vigor of the plants, but an increase in the amount of disease damage.

The bydrogen-1 on concentration of the tops was apparently not markedIy effected by sealing the pots, but that of the roots was genarally decraased. It was decreased in every case with diseased corn and in two out of three cases with the disease free corn. This can be explalned, as later worir will show, on the basis that the disease semed to develop more readily on the sealed roots and they would consequently show less acldity.

Effect of Aeration It is only natural to expect that there would be a deflciency of alr in the sealed pots. If this is the case, then the amount of afr drawn through a pot at each aeration should have an important effect on the growth of the plants.

The apparatus 11 ustrated by plate 2 was designed to test out this polnt. By means of this apparatus it is poselble to draw a measured quantity of alr (10 11ters in this case) through the pots by watching the change of level of the water in the bottles. By having two bottles, as soon as the one is nearly empty, it is possible to roverse the suction and so do away with the necessity of refilling the empty bottle after the withdrawal of each ten liters of water. With the suction force avallable, it took four and one-half to five minutes to draw ten liters of alr through each of the pots.

Twenty pots were set up in each of experiments 3 and 4 . These twentiea were divided Into flve groups which recelved different amounts of aeration, varying from ten 11 ters once a day to none at all. In order to insure a moro complete change of nutrient solution in those pots which were aerated at the longer intervals, the average amount of nutrient solution which was drawn off in Group 1 (Aa1ly aeration) was calculated. Then, during the aeration process and after about three liters of alr had been drawn through the aspirator, this 



\section{$-13-$}

quantity of solution was poured on each of the pots in Group 2. Thres times this quentity was added in Group 3, and so on. In this way the sama total quantity of solution was used in each pot. This, to a certain extent, does away with the possible effect of having unequal quantities of fresh solution In the different pots. For exanple, $100 \mathrm{cc}$ was changed at each daily aeration in Group 1 giving a total of $2800 \mathrm{cc}$ during the growing perlod; by changing 200 cc at each of the every other day aerations in Group 2, the same total quantity of fresh solution was used.

Table 5 glves the results of thase experiments. 

Efrect of Aeratian

Table 5 .

Experiment 3

\begin{tabular}{|c|c|c|c|c|c|c|c|c|}
\hline \multirow{2}{*}{$\begin{array}{l}\text { Descrip- } \\
\text { tion of } \\
\text { pot }\end{array}$} & \multicolumn{3}{|c|}{$\begin{array}{l}\text { Hydrogen-ion } \\
\text { Corcentrstion }\end{array}$} & \multicolumn{3}{|c|}{ Meights } & \multirow{2}{*}{$\begin{array}{c}\text { Amount } \\
\text { of } \\
\text { Aeraticn }\end{array}$} & \multirow{2}{*}{$\begin{array}{l}\text { Nunibey } \\
\text { of D. } \\
\text { Plant }\end{array}$} \\
\hline & So11 Sol. & Tops & Roots & Tors & Roots & Tote? & & \\
\hline D.F.I. & 5.602 & 5.427 & 5.816 & 5.45 & $\begin{array}{l}\text { हrms } \\
3.98\end{array}$ & $\begin{array}{l}\text { gress } \\
9.43\end{array}$ & & 1 \\
\hline P.F. & 5.568 & 5.511 & 6.002 & 2.68 & 1.93 & 4.61 & Daily & 3 \\
\hline D.L. & 5.838 & 5.444 & 5.917 & 4.11 & 3.20 & $7 \cdot 31$ & & 2 \\
\hline p. & 5.483 & 5.444 & 5.983 & 4.62 & 2.95 & 7.57 & & 3 \\
\hline D.F.I. & 5.872 & 5.376 & 5.797 & $5 \cdot 22$ & 4.00 & 9.22 & Every & 2 \\
\hline D.F. & 5.450 & 5.393 & 5.866 & 6.26 & 3.62 & 9.88 & 2 & 1 \\
\hline D.I. & 5.872 & 5.444 & 5.934 & 2.93 & 1.95 & 4.88 & $\operatorname{Daj}_{7}$ & 3 \\
\hline b. & 5.855 & 5.444 & 6.019 & 3.48 & 3.88 & 7.36 & & 3 \\
\hline D. F. I. & 6.092 & 5.461 & 5.883 & 5.65 & 4.38 & 10.03 & Every & 3 \\
\hline p.. & 5.855 & $5 \cdot 521$ & 5.850 & 4.51 & 3.94 & 8.45 & 4 & 2 \\
\hline D.I. & 6.126 & 5.393 & 5.866 & 2.38 & 2.2 .2 & 4.60 & Days & 3 \\
\hline b. & 6.007 & 2.410 & $=$ & 1.36 & .70 & 2.06 & & 2 \\
\hline D.F.L. & 6.075 & 5.427 & 5.797 & 6.50 & 5.85 & 12.35 & Every & 1 \\
\hline D.F. & 6.026 & 5.376 & 5.833 & 3.76 & 2.45 & 6.21 & 8 & 1 \\
\hline D.I. & 6.379 & 5.392 & 5.782 & 2.10 & 1.85 & 3.95 & Days & 3 \\
\hline p. & 6.143 & 5.444 & 5.866 & 2.70 & 2.05 & 4.75 & & 3 \\
\hline D.E.I. & & 5.258 & 5.697 & 5.12 & 6.30 & 11.42 & No & 0 \\
\hline P.F. & & 5.325 & 5.765 & 4.05 & 4.60 & 8.65 & Aera- & 2 \\
\hline P.I. & & $5 \cdot 308$ & 5.748 & 2.66 & 2.13 & 4.79 & t1on & 2 \\
\hline p. & & $5 \cdot 327$ & - & 1.12 & .92 & 2.04 & & 3 \\
\hline
\end{tabular}



Table 5 continued.

Experiment 4

\begin{tabular}{|c|c|c|c|c|c|c|c|c|}
\hline \multirow{2}{*}{$\begin{array}{l}\text { Descrip- } \\
\text { tion of } \\
\text { cot }\end{array}$} & \multicolumn{3}{|c|}{$\begin{array}{l}\text { Hydrogen-1on } \\
\text { concentration }\end{array}$} & \multicolumn{3}{|c|}{ We1ehts } & \multirow{2}{*}{$\begin{array}{c}\text { Amoun } \\
\text { of } \\
\text { Aera }\end{array}$} & \multirow{2}{*}{$\begin{array}{l}\text { No. } \\
\text { of D } \\
\text { Plents. }\end{array}$} \\
\hline & so11 sol. & Tops & Roots & Tops & Roots & TotaI & & \\
\hline D.F.I. & $\begin{array}{c}\mathrm{pH} \\
5.602\end{array}$ & 5.444 & $\begin{array}{c}\mathrm{pF} \\
5.816\end{array}$ & $\begin{array}{c}\text { Grms } \\
5,72\end{array}$ & 3.52 & $\begin{array}{l}\text { Grms } \\
9.24\end{array}$ & Daily & 0 \\
\hline D. F. & 5.365 & 5.325 & 5.833 & 4.78 & 3.97 & 8.75 & & 2 \\
\hline D.I. & 5.773 & 5.410 & 5.951 & 4.00 & 2.76 & 6.76 & & 1 \\
\hline D. & 5.500 & 5.444 & 5.816 & 4.80 & 3.61 & 8.41 & & 2 \\
\hline D.F.I. & 5.720 & 5.461 & 5.883 & 6.93 & 5.71 & 12.64 & Every & 1 \\
\hline D. F. & 5.450 & 5.427 & 5.917 & 5.222 & 3.48 & 8.70 & 2 & 3 \\
\hline D.L. & 5.652 & 5.528 & 6.052 & 3.40 & 2.08 & 5.48 & Pays & 3 \\
\hline D. & 5.382 & 5.511 & 6.002 & 2.98 & 2.20 & 5.18 & & 3 \\
\hline D.F.I. & 5.771 & 5.410 & 5.816 & 5.24 & 3.70 & 8.94 & Every & 1 \\
\hline D.F. & 5.619 & 5.495 & 5.848 & 5.32 & 3.30 & 8.62 & 4 & 3 \\
\hline D.I. & 5.871 & 5.427 & 6.103 & 3.35 & 2.80 & 6.15 & Pays & 3 \\
\hline D. & 5.500 & 5.393 & 5.866 & 3.04 & 1.81 & 3.85 & & 3 \\
\hline D.F.L. & 5.990 & 5.545 & 5.833 & 4.58 & 2.95 & $7 \cdot 53$ & Every & 3 \\
\hline D.F. & 5.754 & 5.444 & 5.833 & 4.87 & 3.74 & 8.61 & 8 & 3 \\
\hline P.I. & 5.990 & 5.393 & 6.255 & 2.60 & 1.76 & 4.36 & peys & 3 \\
\hline D. & 5.754 & 5.528 & $=$ & 1.57 & .61 & 2.18 & & 3 \\
\hline D.F.I. & & 5.393 & 5.799 & 4.02 & 3.57 & 7.59 & No & 3 \\
\hline P.F. & & 5.410 & 5.816 & 5.94 & 5.37 & 11.31 & dera- & 1 \\
\hline P.I. & & 5.361 & 5.834 & 2.55 & 1.98 & 4.53 & tion & 2 \\
\hline p. & & - & - & INo & plants & - & & 3 \\
\hline $\begin{array}{l}\text { D.F.I. } \\
\text { D.F. } \\
\text { D.I. } \\
\text { D. }\end{array}$ & $\begin{array}{l}\text { Disease-Free } \\
\text { Disease-Free } \\
\text { Diseased L1m. } \\
\text { Diseased (INo }\end{array}$ & $\begin{array}{l}\text { Llmed } \\
\text { (No } \operatorname{lin} \theta) \\
\text { d } \\
\lim \theta)\end{array}$ & & & & & & \\
\hline
\end{tabular}



From Table 5 it appears that once a pot is sealed, the amount of artificial aeration 1t receives makes no significant difference to the yield of plents. In both experiments the disease free plants receiving no aeration yielded as well as those aerated dally.

The ancunt of aeraticn does, however, make a difference to the develcpment of the fungus. The progressively decreasing yields of diseased com with the fewer aerations can be attributed to an increasing virulence of the disease. Though the plants in the frequently aerated pots were also diseased, they grew more vigorously wile the pathogenes did not do so well (Plates 4 and 5).

This effect of the seal ir increasing the amount of disease darage is broucht out by Tatle 6 . The data for this table were obtained by counting the number of diseased plants in, (a) the unsealed pots in experiments $11,12,13,(b)$ in all the sealed pots in experiments 11, 12, 13, (c) in all the pots in experiments 4 and 5. This gove the effect of sealed periods of no days, twenty-cne days and twenty-elght days respectively.

Ef fect of Aeration on the Disease

Table 6 .

\begin{tabular}{|c|c|c|c|c|c|c|c|}
\hline \multirow[t]{2}{*}{$\begin{array}{l}\text { Exper - } \\
\text { Iment }\end{array}$} & \multirow{2}{*}{$\begin{array}{l}\text { Days } \\
\text { Under } \\
\text { Senl }\end{array}$} & \multirow[t]{2}{*}{$\begin{array}{l}\text { Total No. } \\
\text { of plants }\end{array}$} & \multirow[t]{2}{*}{$\begin{array}{l}\text { Number in } \\
\text { each set }\end{array}$} & \multicolumn{2}{|c|}{$\begin{array}{l}\text { Percentage } \\
\text { Lime }\end{array}$} & \multicolumn{2}{|c|}{$\begin{array}{l}\text { of D1segsed Plente } \\
\text { No Lime }\end{array}$} \\
\hline & & & & D. F. & D. & D.F. & D \\
\hline $11,12,13$ & 0 & 36 & 9 & $2 \hat{2}$ & 33 & 10 & 55 \\
\hline $21,12,13$ & 21 & 72 & 18 & 28 & 33 & 33 & 83 \\
\hline 4,5 & 28 & 120 & 30 & 50 & 83 & 77 & 93 \\
\hline
\end{tabular}



From Table 6 it appears that the longer the period the plants are under a seal (which is presumably equivalent to the abgence of a free exchange of a1r), the greater is the amount of disease.

What is very interesting in this connection is that lining seens to reduce the number of plents showing pathogenic syuptons, the percentage of apparently disessed plants being reduced from elghty-three to thirty-three in the sealed pots in experiments 11,12 and 13. That $\mathrm{CaCO}_{3}$ should decrease the development of disease is not altogether suprising. From work on pure cultures by Hogidins 13 and Webb ${ }^{29}$, it appears that the most favorable pH on the ac1d side for the developuent of Fusariun and Gibberella saubinet11 is under pHi.5 with a maximum inhibition at between a pH5 to pH6. Consequently the addition of lime should make the soll sclution In the pots less favorable for the development of the disease organisus themselves.

These flr.jirfs show the luportance of giving careful consideration to the effects of 1 iming and sealing in interpreting any of the results obtained by these experiments.

The IJormal Variation in the Hydrogen-1 on Concentration of the Plant Juice and the Correlet1on between this factor and V1gor

The bydrogen-1on of the plant juice is the preduct of a mumber of factors. It cannot be materialiy altered without disturbing the physiological activity of the plant. Therefore, one of the first things to determine in a study of this k1nd, 18 the amount of varlation which con take place in normal plants without any noticeable disturbance in their external development. To do this satisfactorlly calls for a much deeper study than the one made here. It is necessary, however, to get some 1dea of the amount of natural variation, or an effect attributed to lluing or disease lrifection, may be nothing more then an expression of the normal difference, (essuming for the mornent that 

there is such a difference), in hydrogen-ion concentration between the juice of vigorous and less vigorous plants. It was hoped to throw some light on this problem by studying the freen welghts and hydrogen-ion concentration of the plants harvested on the unlined pots, and so determine if there were any corralaticn between these weights and the acidity of the juice. Table 7 gives all these weights and the corresponding $\mathrm{pH}$ values.

\section{Correlation between Vigor and Fydrogen-ion Concentration}

Table 7 .

\begin{tabular}{|c|c|c|c|c|c|c|c|c|}
\hline NTo. & \multicolumn{4}{|c|}{ Tops } & \multicolumn{4}{|c|}{ Root 3} \\
\hline & \multicolumn{2}{|c|}{ D. F. } & \multicolumn{2}{|c|}{ D. } & \multicolumn{2}{|c|}{ D. F. } & \multicolumn{2}{|c|}{ D. } \\
\hline & Teisht & $\mathrm{QH}$ & $\mathrm{me}$ zat & $\mathrm{pH}$ & Teight & $\mathrm{pH}$ & We1 ght & QI \\
\hline 7 & $\begin{array}{l}2.40 \\
3.98\end{array}$ & $\begin{array}{l}5.342 \\
5.473\end{array}$ & $\begin{array}{l}1.45 \\
2.56\end{array}$ & $\begin{array}{l}5.681 \\
5.376\end{array}$ & $\begin{array}{l}2.36 \\
4.76\end{array}$ & $\begin{array}{c}5 \cdot 900 \\
-\end{array}$ & $\begin{array}{l}1.40 \\
1.36\end{array}$ & $\begin{array}{l}5.900 \\
5.748\end{array}$ \\
\hline 8 & $\begin{array}{l}4.35 \\
2.33\end{array}$ & $\begin{array}{l}5.275 \\
5.325\end{array}$ & $\begin{array}{l}4.13 \\
4.52\end{array}$ & $\begin{array}{l}5.303 \\
5.239\end{array}$ & $\begin{array}{l}2.72 \\
1.30\end{array}$ & $\begin{array}{l}5.444 \\
5.562\end{array}$ & $\begin{array}{l}3.63 \\
2.40\end{array}$ & $\begin{array}{l}5.561 \\
5.596\end{array}$ \\
\hline 9 & $\begin{array}{l}3.58 \\
5.55 \\
2.85 \\
2.38\end{array}$ & $\begin{array}{l}5.25 j \\
5.410 \\
5.562 \\
5.444\end{array}$ & $\begin{array}{l}4.22 \\
5.08 \\
2.24 \\
4.13\end{array}$ & $\begin{array}{l}5.410 \\
5.376 \\
5.275 \\
5.511\end{array}$ & $\begin{array}{l}4.20 \\
5.46 \\
6.21 \\
2.47\end{array}$ & $\begin{array}{l}5.510 \\
5.850 \\
5.934 \\
5.799\end{array}$ & $\begin{array}{l}3.55 \\
3.87 \\
2.00 \\
3.12\end{array}$ & $\begin{array}{l}5.085 \\
5.731 \\
5.765 \\
5.951\end{array}$ \\
\hline 10 & $\begin{array}{l}3.66 \\
5.43\end{array}$ & $\begin{array}{l}5.511 \\
5.41,44\end{array}$ & $\begin{array}{l}2.60 \\
2.18\end{array}$ & $\begin{array}{l}3.393 \\
5.511\end{array}$ & $\begin{array}{l}3.33 \\
5.00\end{array}$ & $\begin{array}{l}5.850 \\
5.714\end{array}$ & $\begin{array}{l}1.73 \\
2.28\end{array}$ & $\begin{array}{l}5.765 \\
5.850\end{array}$ \\
\hline 12 & $\begin{array}{l}3.23 \\
2.63\end{array}$ & $\begin{array}{l}5.545 \\
5.562\end{array}$ & $\begin{array}{l}3.40 \\
2.71\end{array}$ & $\begin{array}{l}5.495 \\
5.596\end{array}$ & $\begin{array}{l}2.33 \\
2.72\end{array}$ & $\begin{array}{l}5.951 \\
5.816\end{array}$ & $\begin{array}{l}2.89 \\
2.33\end{array}$ & $\begin{array}{l}6.086 \\
6.036\end{array}$ \\
\hline 12 & $\begin{array}{l}3.73 \\
5.51\end{array}$ & $\begin{array}{l}5.714 \\
5.579\end{array}$ & $\begin{array}{l}2.23 \\
3.20\end{array}$ & $\begin{array}{l}5.647 \\
5.562\end{array}$ & $\begin{array}{l}3.59 \\
3.17\end{array}$ & $\begin{array}{l}6.052 \\
5.900\end{array}$ & $\begin{array}{l}1.56 \\
2.01\end{array}$ & $\begin{array}{l}5.968 \\
5.963\end{array}$ \\
\hline 13 & $\begin{array}{l}2.45 \\
3.74\end{array}$ & $\begin{array}{l}5.545 \\
5.376\end{array}$ & $\begin{array}{l}2.94 \\
2.52\end{array}$ & $\begin{array}{l}5.562 \\
5.444\end{array}$ & $\begin{array}{l}2.32 \\
2.52\end{array}$ & $\begin{array}{l}5.833 \\
5.748\end{array}$ & $\begin{array}{l}1.96 \\
1.63\end{array}$ & $\begin{array}{l}6.019 \\
5.850\end{array}$ \\
\hline
\end{tabular}



From a general survey of this table it appears that there is some correlation between vigor and hydrogen-ion concentration, the more vigorous plants showing tho greater ac1ilty.

The differences are small but in six cases out of seven in disease free tops and in five cases out of seven in diseased tops, the more vigorous plants, judged on a green weight basis, show the greater hydrogen-ion concentration. To a certain extent this can be expected as the more activo motabolisr, which probably goes on in the faster growing plants, would naturally give rise to a larger amount of acid bye-products in the tissues.

The distinction is rot so clear when it comes to the roots. Only in four cases out of six in the disease free plants, and in one case out of seven in the diseased plents, do the more vigorous roots show the greater acidity. Here, however, the complicating factor of disease cornes in. The diseased roots were all so badly ilsessed that, as will be pointed out later, the effect of disease probably overbalarced that of vigor.

\section{A Possible Differance in the Nutrient Reguirements of the Plants}

As the experinents progressed it became evident that lime was having a detrimental effect on the diseased corn.

Munerous workers, among whom are MCCall and Hang ${ }^{13}$, Jones and Sirivel5, Duggar ${ }^{15}$, Salter and MeIlva1ne 22 , and Boagland ${ }^{10}$, have repeatedly shown that the hydrogen-ion concentration of a solution can be changed by the plants growing in 1t. No concluaive evidence has yet been produced, hovever, to show what is the optimun fII value in any solution for the growth of plants. It seens probable that, for the thrae salt solution used, it lies between pH4.8 - 5.2, though considerable departuras from these filgures often have no effect. It seemed, therefore, possible that one reason why the diseased plants 

were not doing well was that lime was making the nutrient solution too alkaline. Beneizel, growing corn in Von der Cronen's solution, was able to show that an acid solution often favors root growth even though it does not give such good results whth the tops. To determine if this were the case here, the hydrogenIon concentration of the nutrient solution in the pots was determined at the end of the growing period in expeziments $4,5,11,12$ and 13 . The results are given in Table 8 .

The Effect of Plants on the Hydrogen-1 on Concentretion of Soll solution Table 8.

\begin{tabular}{|c|c|c|c|c|c|c|c|c|}
\hline INo. & \multicolumn{5}{|c|}{ Iine } & \multicolumn{2}{|c|}{ No Iime } & \\
\hline & & D. F. & & D. & & D. F. & & D. \\
\hline & \multicolumn{8}{|c|}{ Sealed Pots } \\
\hline 4 & 2 & pH 6.092 & 3 & $\mathrm{pH} 6.126$ & 2 & pH 5.855 & 2 & pH 6.007 \\
\hline 5 & 0 & $5 \cdot 771$ & 3 & 5.871 & 3 & 5.619 & 3 & $5 \cdot 500$ \\
\hline 11 & $\begin{array}{l}2 \\
0\end{array}$ & $\begin{array}{l}6.092 \\
5.940\end{array}$ & $\begin{array}{l}1 \\
0\end{array}$ & $\begin{array}{l}6.210 \\
6.092\end{array}$ & \begin{tabular}{l|l}
0 & 1 \\
0 & 1
\end{tabular} & $\begin{array}{l}5.754 \\
5.534\end{array}$ & $\begin{array}{l}2 \\
3\end{array}$ & $\begin{array}{l}5.771 \\
5.788\end{array}$ \\
\hline 12 & 1 & $\begin{array}{l}5.647 \\
5.732\end{array}$ & $\begin{array}{l}0 \\
2\end{array}$ & $\begin{array}{l}6.052 \\
5.664\end{array}$ & $\begin{array}{l}2 \\
1\end{array}$ & $\begin{array}{l}5.596 \\
5.528\end{array}$ & $\begin{array}{l}3 \\
2\end{array}$ & $\begin{array}{l}6.019 \\
5.664\end{array}$ \\
\hline 13 & $\begin{array}{l}1 \\
1\end{array}$ & $\begin{array}{l}5.664 \\
5.702\end{array}$ & $\begin{array}{l}1 \\
2\end{array}$ & $\begin{array}{l}5.731 \\
5.664\end{array}$ & $\begin{array}{l}2 \\
1\end{array}$ & $\begin{array}{l}5.596 \\
5.545\end{array}$ & $\begin{array}{l}2 \\
3\end{array}$ & $\begin{array}{l}5.495 \\
5.528\end{array}$ \\
\hline verage & & $\begin{array}{r}\mathrm{pH5} .836 \\
\pm .039\end{array}$ & & $\begin{array}{r}\text { pII } 5.926 \\
\pm .049\end{array}$ & & $\begin{array}{r}\mathrm{pH} 5.628 \\
\pm .026\end{array}$ & & 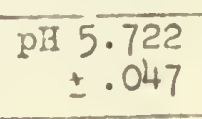 \\
\hline & & & & Unsealed & Po & & & \\
\hline 11 & 0 & 6.278 & 1 & $6 . \overline{312}$ & 01 & 5.585 & 1 & 5.855 \\
\hline 12 & 1 & 5.883 & 0 & 5.968 & 1 & 5.748 & 2 & 5.900 \\
\hline 13 & 2 & 5.681 & 1 & 5.681 & 0 & 5.478 & 2 & 5.579 \\
\hline Average & & 5.947 & & 5.987 & & 5.604 & & 5.778 \\
\hline
\end{tabular}

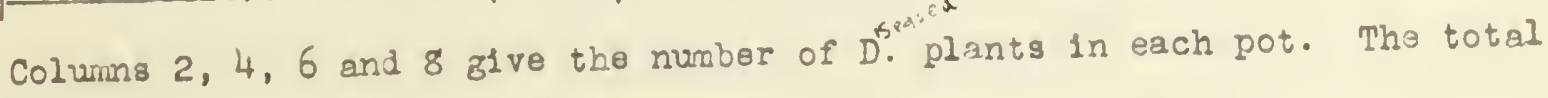
number of plents per pot was three. 

The average difference in $\mathrm{pH}$ of .090 between the lined disease free and diseased pots seens too small to account, on the score of alkalinity, for the wide difference in the yields of the two sets. The interesting thing about Tatle 8 1s, however, that the pots wth diseased plants in them appear to end up generally a littlo less acid than those growing disease free plents. This difference is also brought out by comparing the disease free pots in which same of the plants were diseased. Cenerally the pots harbouring the larger number of diseased plants are less acld than those contalning fewer disessed plants.

The experimental error is too large to make these differences signiflcant, but they seen to 1ndicate a larger absorption of the anion, or acld radicle $\$$, in the nutrient solution by the diseased corn. The possibility that this differance in hudrogen-1on concentration is due to a larger excretion of $\mathrm{CO}_{2}$ by the disease free roots can be dismissed for two reasons: In the first place, any accumulation of $\mathrm{CO}_{2}$ in the pots would have diminlahed the root growth in those pots in experiments 4 and 5 which were aerated only at long intervals - tais did not happen - clements in a recent symposium on aeration summarlzes the work of a muber of 1nvestigators which supports this contention; secondly, the swerp of eir through the pots in the taking of the samples would probably have equalized the $\infty_{2}$ saturation in all the solutions drawn off.

It is not possible to say which of the anions has been absorbed, but as the acidity of the solution $1 \mathrm{~s}$ due to the $\mathrm{H}_{2} \mathrm{PO}_{4}$ ion of the $\mathrm{KB}_{2} \mathrm{PQ}_{4}$, it geems very likely that this ion has boen a borbed for the purpose of supplying either extra $?$ or an acld radicle to the diseased plants.

In interpreting these results, the effect of the sand 1tsalf on the pH of the nutrient solution should be taken into account. Both Shive 24 and 

Hoagland 10 have reported that the hydrogen-ion concentration of a nutrient solution is not markedy affected by the adition of quartz sand. Both these workers, however, washed their sand carefully (\#oagland taking the furthor precaution of treating the sand with HCL) and thoroly flooded the sand at each change of nutrient solution. The sand in this experiment was not washed or so extensively irrigated and an effect of some alkaline reacting materials was noticed. But as this inftial effect would be practically overcome by the and of the growth perlod and would effect both strains in the same way, it does not interfere wh th the comparative value of the hydrogen-ion concentration of the final solutions draw of:. 

Comparison of the Hydrogen-ien Concentration of

Disezsed and Disease Free Corm

Table 9, which gives the hydrogen-ion concentration of all the plants grown in the unlimed pots in experiments 7 to 13 , brings out the differences between the two strains.

Fyarogen-ion Concentration of Diseased and Disease Fres Corn

Table 9

\begin{tabular}{|c|c|c|c|c|c|c|c|c|}
\hline \multirow{3}{*}{$\begin{array}{c}\text { Exper - } \\
\text { Lnent } \\
7\end{array}$} & & \multicolumn{3}{|c|}{ Tops } & \multicolumn{4}{|c|}{ Roots } \\
\hline & & D. F. & & D. & & D. F. & & D. \\
\hline & & $\begin{array}{r}5.342 \\
5.478\end{array}$ & & $\begin{array}{l}5.681 \\
5.376\end{array}$ & & $\begin{array}{c}n+9500 \\
-\end{array}$ & & wh $\begin{array}{r}5.900 \\
5.748\end{array}$ \\
\hline 8 & & $\begin{array}{l}5.275 \\
5.325\end{array}$ & & $\begin{array}{l}5 \cdot 308 \\
5.239\end{array}$ & & $\begin{array}{l}5.444 \\
5.562\end{array}$ & & $\begin{array}{l}5.501 \\
5.596\end{array}$ \\
\hline 9 & $\begin{array}{l}1 \\
1 \\
2 \\
3\end{array}$ & $\begin{array}{l}5.255 \\
5.410 \\
5.56 \hat{c} \\
5.444\end{array}$ & $\begin{array}{l}2 \\
1 \\
2 \\
3\end{array}$ & $\begin{array}{l}5.410 \\
5.376 \\
5.275 \\
5.521\end{array}$ & $\begin{array}{l}1 \\
1 \\
2 \\
3\end{array}$ & $\begin{array}{l}5.510 \\
5.850 \\
5.934 \\
5.799\end{array}$ & $\begin{array}{l}2 \\
1 \\
2 \\
3\end{array}$ & $\begin{array}{l}5.985 \\
5.731 \\
5.765 \\
5.951\end{array}$ \\
\hline 10 & $\begin{array}{l}0 \\
1\end{array}$ & $\begin{array}{l}5.511 \\
5.544\end{array}$ & $\begin{array}{l}2 \\
3\end{array}$ & $\begin{array}{l}5.393 \\
5.511\end{array}$ & $\begin{array}{l}0 \\
1\end{array}$ & $\begin{array}{l}5.350 \\
5.714\end{array}$ & $\begin{array}{l}2 \\
3\end{array}$ & $\begin{array}{l}5.765 \\
5.850\end{array}$ \\
\hline 11 & $\begin{array}{l}0 \\
0\end{array}$ & $\begin{array}{l}5.545 \\
5.562\end{array}$ & $\begin{array}{l}2 \\
3\end{array}$ & $\begin{array}{l}5.495 \\
5.596\end{array}$ & $\begin{array}{l}0 \\
0\end{array}$ & $\begin{array}{l}5.951 \\
5.816\end{array}$ & $\begin{array}{l}2 \\
3\end{array}$ & $\begin{array}{l}6.086 \\
6.036\end{array}$ \\
\hline 12 & $\begin{array}{l}2 \\
1\end{array}$ & $\begin{array}{l}5.714 \\
5.579\end{array}$ & $\begin{array}{l}3 \\
2\end{array}$ & $\begin{array}{l}5.647 \\
5.562\end{array}$ & $\begin{array}{l}2 \\
2\end{array}$ & $\begin{array}{l}6.052 \\
5.900\end{array}$ & $\begin{array}{l}3 \\
2\end{array}$ & $\begin{array}{l}5.968 \\
5.968\end{array}$ \\
\hline 13 & 2 & $\begin{array}{l}5.54 \overline{5} \\
5.376\end{array}$ & $\frac{2}{3}$ & $\begin{array}{l}5.562 \\
5.444\end{array}$ & $\begin{array}{l}2 \\
1\end{array}$ & $\begin{array}{l}5.833 \\
5.748\end{array}$ & $\begin{array}{l}2 \\
3\end{array}$ & $\begin{array}{l}6.019 \\
5.850\end{array}$ \\
\hline & 14 & $\begin{array}{c}A v .460 \\
\pm \quad .021\end{array}$ & $2 z$ & $\begin{array}{r}5.462 \\
\pm .021\end{array}$ & 14 & $\begin{array}{r}\text { Av } 5.791 \\
\pm \quad .029\end{array}$ & 28 & $\begin{array}{r}\text { Av. } 5.861 \\
\pm \quad .023\end{array}$ \\
\hline
\end{tabular}

Coluns 2, 4, 6 and 8 give the number ce diseased plarts in each pot. The total number of plants per pot was 3. 

This table showe that there is no specific difference in hydrogen-ion concentration between the two strains. The acldity of the two sets of tops (pE 5.460 and 5.462) is practically the same and the difference in the roots is not signiflcant.

Then, however, disease free or diseased plants in the same experiment (such as those in the two disease free pots in experinent 12) are compered Inter se, the pots with the smaller number of diseased plants will generally be found to contain the plants with the more acia juice. Thls holds true, where date are avellable, in three cases out of four in disease free tops, four cases out of flve in diseased tops, three out of four with disease free roots and one cut of ilve cases with disessed roots. It is again difficult to see why the diseased roots do not follow the general lead of the tops. However, the diseased rocts were noerly all so badly diseased that some plants among them classified as apparently disease free may have been dissased. In ary case, it is 81 gniflcant that this group has the lowest average hvdrogenIon concentration.

Thether this lowering of aclity is directly due to the activities of the disease organlsms, or to a lowering of the vigor of the plants, or to both, is not clear. It was pointed out in the introduction to this article that an alteration in the acidity of tice plant juice, as the result of the developinent of pathological ccnditions, has been reported by several writers. Amone these workers are Hoffer and Carr ${ }^{11}$; R. B. Harveys; Freeman We1se and Harvey30; and Vagner28. The work of the last named investigator is of particular interest in this connection. After he had injected the disease cultures into the tis sues of various succulert plants, he managed to follow the actual development of the disease. He found at first a decided increage In the hydrogen-ion concentration which was followed by a return to the 

normal of the plant if it were going to recover, but by a decrease in acidity if It were golng to succunb. The diseased plants reported in Table 9 seen to ehow a lowering of hydrogen-ion concentration very similer to the premortel drop in Wagner's infected plants.

\section{Influence of Liming on the Yleld of Corn}

Ilring is popularly supposed to be beneficlal to diseased corn, and one object of these experiments was to determine whether this improvement is Que to a specific effect of the lime on the diseased corn, or to the general Improved soil conditions brought about by 1ts application.

Ary effect obtained by the additicn of $\mathrm{CaCO}_{3}$ in these experiments world probably be due elthar to its speciflc properties or to its physiological effect on the plant itself, for it is hard to see how liming can have any signiflcart effect on the physical or blological conditions in the kind of sard used for experinents.

In each set of experimentz half the pots were always linad and balf left unlimed as checls. The ylelds of the two sets are given in Table 10 . 

Elfect of Iimfin on the yield of Com

Tabie 10.

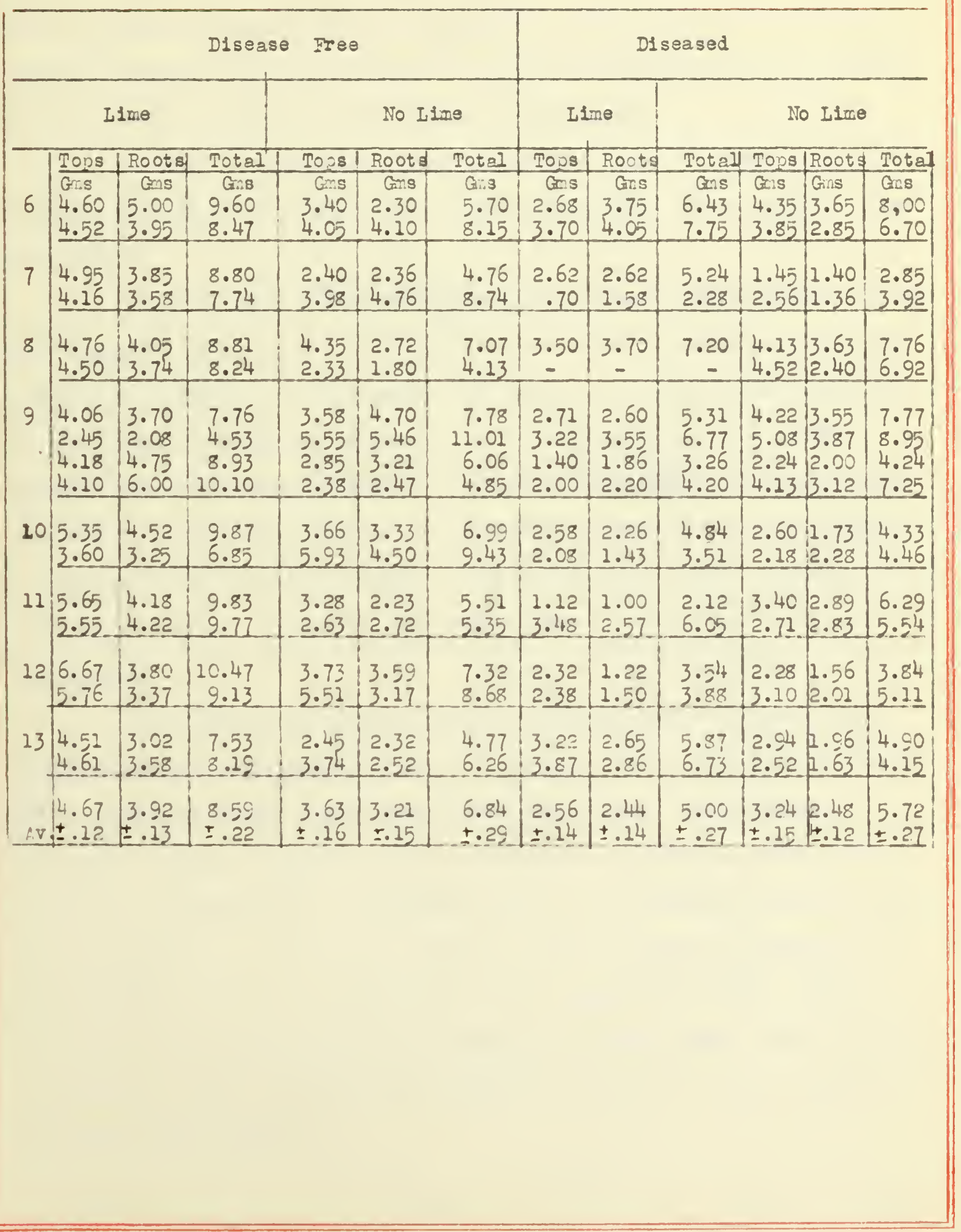



These results are very interesting as the adition of lime, while it significantly Increosed the average vield of tops rocts and green welcht in the case of disease free corn, was not favorable to diseased corn. There was a marked decrease in the green woleht of tops in the diseased corn and certainly no Iruprovement in rogard to rocts or totel green weight.

As limine redused the number of disessed plants in these experiments, It seems strange thet it should have reacted unfavorably on the yield of these sene plants.

It would seew thet either $\mathrm{CaCO}_{3}$ has decreased tine avaliability of the acid phosplete radicle itich, as brought out by Trble 8, may be more urgently required by diseased than by disease free plants - in the presence of the $\mathrm{CO}_{2}$ of the roots, the $\mathrm{CaCO}_{3}$ xay have done this by camblning with some of the $\mathrm{KH}_{2} \mathrm{PO} 4$ to form less soluble CalpO4 - or, as True 25 pointed out in an opposite connection, It thay have affected the aboorptive properties of the cell walls In some way so as to render certain of the fons in the nutrient solution phyelologically less avallable. The fomer seems to be the xore reasonable explanat1on.

It hardy needs pointing out here that temperature relations are very inportant in studying the effests of calclum. These results were obtained at a terpereture of $20^{\circ}-25^{\circ} \mathrm{C}$ and mey not hold at other temperatures. Porthelm21, gowing beans in nutrient solutions, showed that the demand for $\mathrm{Ca}$ rose 28 the temperature was increased, and in the preliminary moisturo tests run to determine the optimns scil molsture content for these experinents, Ca gave favorable effects on diseased planto at a temperature of $32^{\circ}-37^{\circ} \mathrm{c}$. When there is a variation in time planting or season, wome of the seenlngly inconsistent results obtained in the field ma.y be due to a similar change in the temperature relations. 

Influence of Iiring on the Hyarogen-10n

Concentration of the Juice

Frori the work of Hass ${ }^{6}, \mathrm{Clevenger}^{4}$, Truog and Meacham 26 , it was expected that liming wolld reduce the acldity of the plant juice. In these experiments 1t did not significantly do so. This is brought out by Table 11 , which gives the hydrogen-10n concentration of all the plants grown in expericents $7-13$.

$\frac{\text { Influence of Liming on the Fydrogen-ion }}{\mathrm{C} \text { Concentration of the Juice }}$

Table 11.

Disease Treo

Diseased

\begin{tabular}{|c|c|c|c|c|c|c|c|c|}
\hline & \multicolumn{2}{|c|}{ Tops } & \multicolumn{2}{|c|}{ Poots } & \multicolumn{2}{|c|}{ Tors } & \multicolumn{2}{|r|}{ Roots } \\
\hline & $\begin{array}{c}\mathrm{ILCC \theta} \\
\mathrm{pH}\end{array}$ & No Line & $\begin{array}{c}\text { LIme } \\
\mathrm{pH}\end{array}$ & No IIne & $\begin{array}{c}\text { Lime } \\
\mathrm{pH}\end{array}$ & $\begin{array}{c}\text { No IIre } \\
\mathrm{pH}\end{array}$ & $\begin{array}{c}\operatorname{Lime} \\
\mathrm{pH}\end{array}$ & $\begin{array}{c}\text { No } \underset{\mathrm{LI}}{\mathrm{pH}} \\
\mathrm{c}\end{array}$ \\
\hline 7 & $\begin{array}{l}5.495 \\
5.427\end{array}$ & $\begin{array}{l}5.342 \\
5.478 \\
\end{array}$ & $\begin{array}{l}5.816 \\
5.731\end{array}$ & 5.900 & $\begin{array}{c}5.647 \\
-\end{array}$ & $\begin{array}{l}5.681 \\
5.376\end{array}$ & $\begin{array}{c}5.900 \\
- \\
\end{array}$ & $\begin{array}{l}5.900 \\
5.748\end{array}$ \\
\hline 8 & $\begin{array}{l}5.393 \\
5.359\end{array}$ & $\begin{array}{l}5.275 \\
5.325\end{array}$ & $\begin{array}{l}5.816 \\
5.934\end{array}$ & $\begin{array}{l}5.444 \\
5.562\end{array}$ & 5.410 & $\begin{array}{l}5.308 \\
5.239\end{array}$ & $\begin{array}{c}5.681 \\
-\end{array}$ & $\begin{array}{l}5.561 \\
5.596\end{array}$ \\
\hline 9 & $\begin{array}{l}5.393 \\
5.427 \\
5.495 \\
5.410\end{array}$ & $\begin{array}{l}5.255 \\
5.410 \\
5.562 \\
5.444\end{array}$ & $\begin{array}{l}5.816 \\
5.866 \\
5.900 \\
6.052\end{array}$ & $\begin{array}{l}5.510 \\
5.850 \\
5.934 \\
5.799\end{array}$ & $\begin{array}{l}5.428 \\
5.511 \\
5.562 \\
5.359\end{array}$ & $\begin{array}{l}5.410 \\
5.376 \\
5.275 \\
5.511\end{array}$ & $\begin{array}{l}6.137 \\
6.188 \\
6.102 \\
6.103\end{array}$ & $\begin{array}{l}5.985 \\
5.731 \\
5.765 \\
2.951\end{array}$ \\
\hline 10 & $\begin{array}{l}5.562 \\
5.613\end{array}$ & $\begin{array}{l}5.511 \\
5.444\end{array}$ & $\begin{array}{l}5.799 \\
5.917\end{array}$ & $\begin{array}{l}5.850 \\
5.714\end{array}$ & $\begin{array}{l}5.461 \\
5.359\end{array}$ & $\begin{array}{l}5.393 \\
5.511\end{array}$ & $\begin{array}{l}5.799 \\
5.816\end{array}$ & $\begin{array}{l}5.765 \\
5.850\end{array}$ \\
\hline 21 & $\begin{array}{l}5.528 \\
5.478\end{array}$ & $\begin{array}{l}5.545 \\
5.562\end{array}$ & $\begin{array}{l}5.782 \\
5.799\end{array}$ & $\begin{array}{l}5.951 \\
5.816 \\
\end{array}$ & 5.579 & $\begin{array}{l}5.495 \\
5.596\end{array}$ & $5 . \overline{9} 00$ & $\begin{array}{l}6.086 \\
6.036\end{array}$ \\
\hline 12 & $\begin{array}{l}5.478 \\
5.647\end{array}$ & $\begin{array}{l}5.714 \\
5.579\end{array}$ & $\begin{array}{l}5.782 \\
5,883\end{array}$ & $\begin{array}{l}6.052 \\
5.900\end{array}$ & $\begin{array}{l}5.596 \\
5.579\end{array}$ & $\begin{array}{l}5.647 \\
5.562\end{array}$ & $\begin{array}{l}5.951 \\
5.934\end{array}$ & $\begin{array}{l}5.968 \\
5.968\end{array}$ \\
\hline 13 & $\begin{array}{l}5.511 \\
5.342\end{array}$ & $\begin{array}{l}5.545 \\
5.376\end{array}$ & $\begin{array}{l}5.866 \\
5.731\end{array}$ & $\begin{array}{l}5.833 \\
5.748\end{array}$ & $\begin{array}{l}5.410 \\
5.410 \\
\end{array}$ & $\begin{array}{l}5.562 \\
5.5444\end{array}$ & $\begin{array}{l}5.816 \\
5.985\end{array}$ & $\begin{array}{l}6.019 \\
5.850\end{array}$ \\
\hline Av. & $\begin{array}{l}5.472 \\
\pm .014\end{array}$ & $\begin{array}{r}5.460 \\
\pm .020\end{array}$ & $\begin{array}{r}5.849 \\
\pm .013\end{array}$ & $\begin{array}{r}5.790 \\
\pm .029\end{array}$ & $\begin{array}{r}5.485 \\
\pm .018\end{array}$ & $\begin{array}{r}5.462 \\
\pm \quad .022\end{array}$ & $\begin{array}{r}5.947 \\
+.024\end{array}$ & $\begin{array}{r}5.861 \\
-\quad .025\end{array}$ \\
\hline
\end{tabular}



hydrogen-ion concentration, the differences are not large enough to be signif1cant. What may have bappened is brought out by Table 12, which surnarizes the simulaneous effect of liming on acidity and yield (Tables 10 and 11). A plus value in the pE colum of Table 12 naturally indicates a decrease in acidity. Sumery of the Influence of Liring on Hydrogen-1on Concentration and Yield

Table 12

\begin{tabular}{|c|c|c|c|c|c|c|c|c|}
\hline \multicolumn{3}{|r|}{ Disease } & Free & & \multicolumn{4}{|c|}{ Diseased } \\
\hline \multicolumn{3}{|c|}{ Tops } & \multicolumn{2}{|c|}{ Roots } & \multicolumn{2}{|c|}{ Togs } & \multicolumn{2}{|c|}{ Roots } \\
\hline & $\begin{array}{c}\text { Average } \\
\text { Yleld }\end{array}$ & $\begin{array}{c}\text { Average } \\
2 H\end{array}$ & $\begin{array}{c}\text { Average } \\
\text { Yleld }\end{array}$ & $\left\{\begin{array}{l}\text { Average } \\
\mathrm{pH}\end{array}\right.$ & $\begin{array}{c}\text { Average } \\
\text { Yleld }\end{array}$ & $\begin{array}{c}\text { Average } \\
\mathrm{DE}\end{array}$ & $\begin{array}{c}\text { Average } \\
\text { Yield }\end{array}$ & $\begin{array}{c}\text { Average } \\
\mathrm{pH}\end{array}$ \\
\hline 7 & $+1.36 \mathrm{gms}$ & +.051 & $T .15 \mathrm{gms}$ & -.126 & $-.34 \operatorname{gms}$ & +.118 & $+.72 \mathrm{gm}$ & +.076 \\
\hline 8 & +1.29 & +.076 & +1.63 & +.372 & -.82 & +.136 & +.68 & +.102 \\
\hline 9 & +.11305 & +.013 & +.30 & +.135 & -1.58 & +.072 & -.58 & +.274 \\
\hline 10 & -.07 & +.110 & -.03 & +.076 & -.06 & -.042 & -.16 & \pm .0 \\
\hline 12 & +2.64 & -.050 & $+1 \cdot 72$ & -093 & -.75 & +.033 & -1.07 & -.161 \\
\hline 12 & +1.59 & -.084 & +.20 & -.143 & -.34 & -.017 & -.42 & -.025 \\
\hline 13 & +1.46 & -.034 & +.88 & +.008 & +.81 & -.093 & +.96 & -.34 \\
\hline
\end{tabular}

From Table 12 it appears that the hydrogen-ion concentration of the tops may bo actually increased in case of plants mariedly benefitted by the application of lime. This increese is shown by the disesse free tops in experinents 11,12 and 13, where $11 \mathrm{ming}$ produced 1 te meximum favorable effect, 

and by the diseased tops in experiments 10, 12 and 13 (though not in 7) where the effect of liming, though not favorable, was least detrimental.

The effect of Ilning on the hydrogen-ion concentration of the roots seems to follow no sort of recognizable rule. The acidity actually increased Wh thout any particular relation to yield in three cases out of seven in both the disease free and diseased com.

\section{All through these experiments the reactions of the roots are far} harder to explain then those of the tops. The reason for this may ba in some Intemal regulatory power of the roots. Probably they can regulate their hydrogen-1 on concentration, desplte the I1no, ao as to function physiologically as well as possible for the conditicns under which they have to grow. This power of the roots is brought out by Table 5 where, desplte wide variations in the hydrogen-ion concentration of the nutrient solution in the pots, the ecldity of the roots shows very little change. In experiment 3 , the roots in the disease free limod pots, whth a variation in $\mathrm{pH}$ of the soll soluticn of pH 5.602 to $\mathrm{pH}$ 6.092, show a variation of only pH .085. In experiment 4, with approximately the same soll range, the sane plants show a root varlation of only pH .051.

This power of the roots to largely regulate their own hidrogen-ion concertration seems to be one explanation why hypotheses, which fit the reactions of the tops so well, are not nearly so satisfactory for the roots.

In conclusion it may be well to point out that a great deal of the veriation obtalned in experiments on corn root and stalk diseases is probably due to differences in the seasonal vigor of the plants. Any treatment or favorable environfental condition, which increases the vigor of the plant, probably increaseg 1ts resistance to disease. If the season or soll treatment is rendered more favorable to a vigorous growth of the corn plant, strains which one season show a large percantage of disease, in the next may shov 



\section{$31-$}

only a slight amount of infection.

A very large proportion of the seed corn in the corn belt is infected with organistus capable of producing a diseased condition of the root or stern, but how mach of this disease will actualiy develop depends on both the inherent vigor of the plants and on the environnental conditions.

The worl reported in this paper tends to show that whenever the conditions are rendered unfavorable to the developrent of the plant elther by sealing the pots, reducing aeration, applying $\mathrm{CaCO}_{3}$ or reduclns the percentage of soll moisture, there is an fumediate increase in the enount of disease danage in the diseased corn. Thls increase is due largely to the fact thet the diseased corn, being less vigorous then the disease free, is not so able to withstand the unfavoreble environment and 13 thus more reajily susceptiblo to the attacks of pathogenes. Unter happler clrcuinstances the diseassd plants could probably bold their own. The environmental conditions may play nearly as important a role in overconlng disease infection as any inharent resistance In the seed 1tself. 

SUIAIARY

The value of these results $1 \mathrm{~s}$ sonewhat mininlzed by the fact that the seed used was not entirely disease free or diseased. There seens to be, however, sufficient difference in the severity of disease infection in the two strains to allow the following conclusions to be drawn:

For plants grom under the experinental conditions doscribod it appears that:

(1) Unt1l the diseased condition is well developed, there is no Bignificant difference between the bylrogen-1on concentration of com showing a large percentage of infection on the gerininator and that showing a smaller percentage.

(2) The effect of the disease is to reduce the hylrogen-1on concentration of the plant julce.

(3) There is a correlation between the vigor of the plant and the hijirogention concentration of the julce, the more vigorous plants usually being the more ac1d.

(4) Ilne decreases the yield of badiy diseased com but increases that of com showing a slight amount of infoction. This may be due to a larger demand by the diseased corn for the phosphate radicle in the nutrient solution.

(5) Liming seems to have no specific effect on tho hylrogen-ion concentration of the plant julee. Where 1t increases the vigor of the plants It incraases the hylrogen-10n concentration and vice versa. 



\section{$-33-$}

Part II

\section{INTRODUCTION}

This field trial was planned to deterwine whether it is possible to detect any difference in the hydrogen-ion concentration of the plant juice of apparently diseased and disease free com grown under field conditions. It was also planned to secure at the same time some data on the norral variation In hydrogen-ion coneentration due to such factors as Age, Neather and Iiming. The methods involved are of necessity rough, but they indicate the changes that may bo expected in ordinary farm practice.

The 11terature covering such a broad investigation is naturally very extensive. Io atterpt is male to give it full treatment bere. There are good descriptions of the diseage and its development in the publications of the United States Department of Arriculture, Ill1no1s, Purdue, Delaware, Kentucky and other experiment stations 31 , wher corn root rot has been carefully studied under fleld conditions. 



\section{MATARIALS}

Soll A feiriy unfform piece of land with a slight southern slope and about one-half acre in extent was chosen for this experlment. The soll of the plot is a brom silt loam, typical of central Illinois. It had grown alfalfa from 1913 to 1915, corn in 1919, oats in 1920. In 1919 and 1920, two tons of chicken manure were applied to it each year.

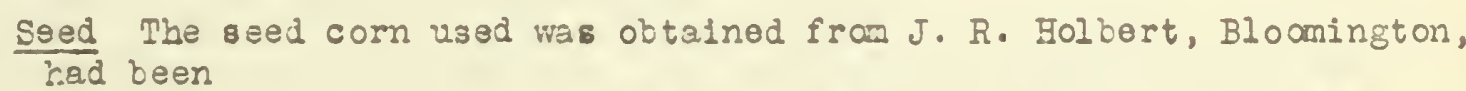
Illinols, and carefully selected to give disease free, diseased composite (seed infected with either Fusarium, or Diplodia, or both), Diplodia infected, Fusarium infected and narly disease free sead (no Diplodia or Fusarium inlection).

As the experiment progressed no difference in hydrogen-ion concentration could be noticed between the different stralns. Therefore, in order to narrow down the problem, only plents in the disease free and diseased composite rows were used in securing data for the finel results.

Twenty rows of com were planted, four of each kind. Each row consiated of forty hills, excluding guard rows, with three kemals to the hill. The rows ran north and south.

Lime was applied east and wost over the southern half of the plot at the rate of twelve tons per acre. In each row twenty hills ware therefore on Ilmed and twenty on unlimed so11. Two guard rows separated the IImed from tho unlimed corn.

Course of Groivth The plot was planted with a hand planter on May 18, 1921. Heavy rains on May 26 washed out one comer of the limed part of the field and it was necessary to replant this May 31. This com never quite caught up to the earlier planting and it was not possible to use any of it until near the end of the experiment. The plot was cultivated on June 7 and 8. 

Up to the midde of July very little difference was noticeable between the diseased and disease free com, or between the limed and unlimed rows. The whole crop made a $\nabla 1$ gorous growth and gennination, tassel and smut counts did not show any marked difference either between the different strains or from the IIme treatment.

on July 27, ten leaning stalks were noticed in the Diplodia and D1seased Composite rows on the unlimed so1l. On July 31, there were thirty lesning stalks on tive unlired and twelve on the limed soll distributed without mach difference between the various rows. During august the Iimed plot gradualiy improved in comparison with the unlined and by Septarnber showed deeldedly the more vigorous stant. A count of learing stalks made on September I, disclosed forty-ifve leaning stalks on the unlimed and eightsen on the IImed so11.

The com matured about september 21. No goneral harvest was made, however, as a large number of plants had been pulled up indiscriminately for testing purposes, which made it imposible to get a truly comparative count on the rewaining rows. 



\section{METEODS}

Plants were collected at irregular intervals throughout the groving season.

In this experiment there was no noticeable difference in the apperance of the diseased ard disease free plants in their earlier stages of growth. Tize plants pulled in the diseased and disease free rows all seened externally healthy Therefore, In order to secure unfformity, the practice of oniy pulling plants whlch semod externaly disease free from both the diseased and disease froe rows was adhered to unt1l the ond of the experiment. When obviously diseased naterlal became available in August and september, it was harvested and exarined quite separately. In this way, os suraing the com was diseased and disease Pree as described, 1t should be possible to show whether any change in hydrogen-1 on concentration preceded or followed the devalopment of the disease. Plants were dug up by the roots and conveyed at once to the laboratory. In each case the plants selected were extermally sound and typlcal of the general state of developnent of the crop at the time. Each sanple consisted of three plants from separate hills. Samples were always taken between 8 and 9.m.

The laboratory cethods and procedure were essentially similer to those described in the forepart of this peper.

A section 2" long wlth the lower node in conter was cut from each plant and the brace roots trlamed off. The three nodes were sliced up and then passed through a tinned meat grinder. As there was very 11ttle adherent soll on these nodes, they were not washed before grinding.

The rocts, on the other hard, were flrst washed in tap water until Pree fror soll. Then twice rinsed in distllied water end dried with a clean towel. An allquot sample of the roots of each of the throe plents was then taken and the bixture passed through the grinder. 

All teets were run in duplicate and the apparatus repeatedly checked against a TH Pthalate solution of incwn hvorogen-ion concentration.

\section{RESULTS AND DISCUSSION}

Under centrolied conditions the acldity of the plant juice is held to vary with the time of day, etmospheric conditlons and age of the plant. The effect of these factors on the two stralns of corn had, therefore, to be first deternined before any sat1sfectory comperison cculd be made of their hydrogenIon concentraticns.

To determine thls effect approximately, a record of the temperature, atmopierlc bumldity, shy conditlons and stage of maturity of the plants was kept throughout the experiments. At the end of the experimert this data was plotted to find out whether there was any traceable correlation between these enviromental factors and the hydrogen-1on concentration of the plents.

The weather rscords were cttalned fral. the University of IlIinois Feather Station. The stege of maturity wae thet shown by those plants actraliy priled for testlng.

The date obtaired are sumarized in the following tables. UnfortunateIy they apply to only one sesson and so cannot be taken as giving more than an Indication of what may go on in the plant.

\section{The Influerce of the Tiwe of Day on the Hydrogen-1on Concentration of the Plant Juice}

fs all sawples were collected between 8 and 9 a.m., It ws not thought necessery, for the purposes of this experlment, to speclficelly check the diurnal varlation in hydrogen-ion concentration. 



\section{$-38-$}

The Influence of Atmospheric Conditions on the Eydrogen-1 on

\section{concentration of the Plent Juice}

A record of the atrospheric conditions at the time the plants were collected was obteired each day from the University Weather Staticn. These data were surmerized at the end of the season so as to find out if there were any correlaticn between the environmental condltions and the acidity of the plant iuice. Unfortunately no deterinations were made of soll mc1 sture, which may have had a potent effect on the results.

The plants used in conpling the data on atmospherle conditions were all grown on the unlimed s011. The results are sumarlzed in Table 2.

\section{Elfect of the Atrospierlc Conditicns on the}

Hydrogen-1cn Concentration of the plant julce

Table 1.

\begin{tabular}{|c|c|c|c|c|c|c|}
\hline Date & $\begin{array}{c}\text { Disease } \\
\text { Froe }\end{array}$ & Diseased & Sky & Rel. Humldity & Temp. & $\begin{array}{l}\text { Atmospherlc } \\
\text { conditions for } \\
\text { previous } 24 \text { ins }\end{array}$ \\
\hline $\begin{array}{r}7 \\
18 \\
28\end{array}$ & $\begin{array}{l}5 \cdot 740 \\
5 \cdot 765 \\
5.444\end{array}$ & $\begin{array}{l}5.807 \\
5.647 \\
5.410\end{array}$ & $\begin{array}{l}\text { cloudy } \\
\text { clear } \\
\text { cloudy }\end{array}$ & $\begin{array}{l}62 \% \\
57 \\
42\end{array}$ & $\begin{array}{l}81^{\circ} \mathrm{F} \\
75 \\
90\end{array}$ & $\begin{array}{l}\text { cloudy } \\
\text { clear } \\
\text { cloudy }\end{array}$ \\
\hline 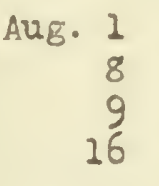 & $\begin{array}{l}5.511 \\
5.782 \\
5.731 \\
5.800\end{array}$ & $\begin{array}{r}5 \cdot 545 \\
5.441 \\
5.748 \\
5 \cdot 716\end{array}$ & $\begin{array}{l}\text { cleer } \\
\text { clear } \\
\text { clear } \\
\text { cloudy }\end{array}$ & $\begin{array}{l}55 \\
63 \\
74 \\
79\end{array}$ & $\begin{array}{l}70 \\
66 \\
63 \\
63\end{array}$ & $\begin{array}{l}\text { clear } \\
\text { cloudy } \\
\text { clear } \\
\text { cloudy }\end{array}$ \\
\hline $\begin{array}{r}\text { Sept. } 7 \\
13 \\
20 \\
26 \\
\end{array}$ & $\begin{array}{l}5.427 \\
5.508 \\
5.511 \\
5.562\end{array}$ & $\begin{array}{l}5 \cdot 461 \\
5 \cdot 579 \\
5 \cdot 596 \\
5 \cdot 748\end{array}$ & $\begin{array}{l}\text { clear } \\
\text { cloudy } \\
\text { clear } \\
\text { clear }\end{array}$ & $\begin{array}{l}69 \\
72 \\
92 \\
42\end{array}$ & $\begin{array}{l}66 \\
69 \\
72 \\
70\end{array}$ & $\begin{array}{l}\text { clear } \\
\text { cloudy } \\
\text { cloudy } \\
\text { cl cudy }\end{array}$ \\
\hline
\end{tabular}

According to the standard texts of Pfeffer and Jost, 11 lunination, high temperature, and any influencos which Induce "coplous transplration", decrease the ecldity of the sap. Slnilarly Long, In some more recent work, 

was able to show that the acidity of the outer regions of certain cacti was markedly decreased by the jolnt influence of light and temperature.

From Table 1, it would seem, hovever, that the acldity of the corn under study was controlled by physlologlcal factors, which were stronger than the enviroment. On July 28, for instarce, when a relative decrease of acidity was expected, the very reverse condition took place. Strilarly on August 16 , when with a relat1vely high bumility and low temperature, an acld sep was looked for, the lowest hudrogen-1 an corcentration of the season was recorded. Elther the variation in early corning and over night atmospheric conditions was not severe encugh to bring about a noticeable change in acidity, or else the methods of sampling were too rough to detect it. Wat is signiflcant for our purpose is, however, that tho diseased and disease free strains both seem to vary in the saine direction.

\section{Effect of Age on Fydrogen-ion Concentration}

Ta1s was studied on apparently unirifected diseased and disease free plants from the unlined soll. Tho results are given in Table 2 and are 11lustrated by FIgure 1. 

The Effect of Age on the Eydrogen-1on Concentretion

Of the Plant Juice

Table 2.

\begin{tabular}{|c|c|c|c|c|}
\hline Date & $\begin{array}{l}\text { Age in } \\
\text { Days }\end{array}$ & D1sease Free & Diseased & $\begin{array}{l}\text { Stage of } \\
\text { Development }\end{array}$ \\
\hline $\begin{array}{r}7 \\
18 \\
28 \\
\end{array}$ & $\begin{array}{l}50 \\
61 \\
71 \\
\end{array}$ & $\begin{array}{l}5.740 \\
5.765 \\
5.444 \\
\end{array}$ & $\begin{array}{r}5.807 \\
5.647 \\
5.410 \\
\end{array}$ & $\begin{array}{l}\text { Pegetativo } \\
\text { Tassel } \\
\text { MIK }\end{array}$ \\
\hline $\begin{array}{r}1 \\
9 \\
16 \\
\end{array}$ & $\begin{array}{l}74 \\
82 \\
89 \\
\end{array}$ & $\begin{array}{l}5.511 \\
5.731 \\
5.800\end{array}$ & $\begin{array}{l}5.545 \\
5.748 \\
5 \cdot 716\end{array}$ & Soft dough \\
\hline $\begin{array}{r}\text { Sept. } 7 \\
13 \\
20 \\
26\end{array}$ & $\begin{array}{l}111 \\
117 \\
124 \\
130\end{array}$ & $\begin{array}{l}5.427 \\
5.508 \\
5.511 \\
5.562\end{array}$ & $\begin{array}{l}5.461 \\
5.579 \\
5.596 \\
5 \cdot 748\end{array}$ & $\begin{array}{l}\text { Dough } \\
\text { Glazing } \\
\text { Ripe }\end{array}$ \\
\hline
\end{tabular}

The greatest hydrogen-1 on concentration was reached about the milk

stage with a subsequent gradual disappearance of acldity as maturity was approach ed. The variation ran almost parallel in the two strains and the assurned presence of disease does not seem to have interferred at all with tho normal physlologlcal changes. Ho explanation occurs to us for the extremely low hydrogenIon concentration in Aurust. Fram the temperature and hunldity records the very opposite was expected.

Since environment and age seem to effect the two straing to the same degree, we are probably justifled for the time boing in neclecting the effect of these factors. For experimertal simplicity this assuption has been adhered to throughout thls paper.

The hydrogen-1on concentration comparisons are made wth julce extracted from the lower node. This node was chosen for two reasons: (a) it seemed the most likely part of the stem to show diseese symptors, (b) a very constant relation was found to exist between the hydrogen-1on concentration of the lower node and that of the roots. This is brought out by Table 3 and FIE. 2. 

Graph 1llustrating the influence of age on hydrogen-1on concentration.

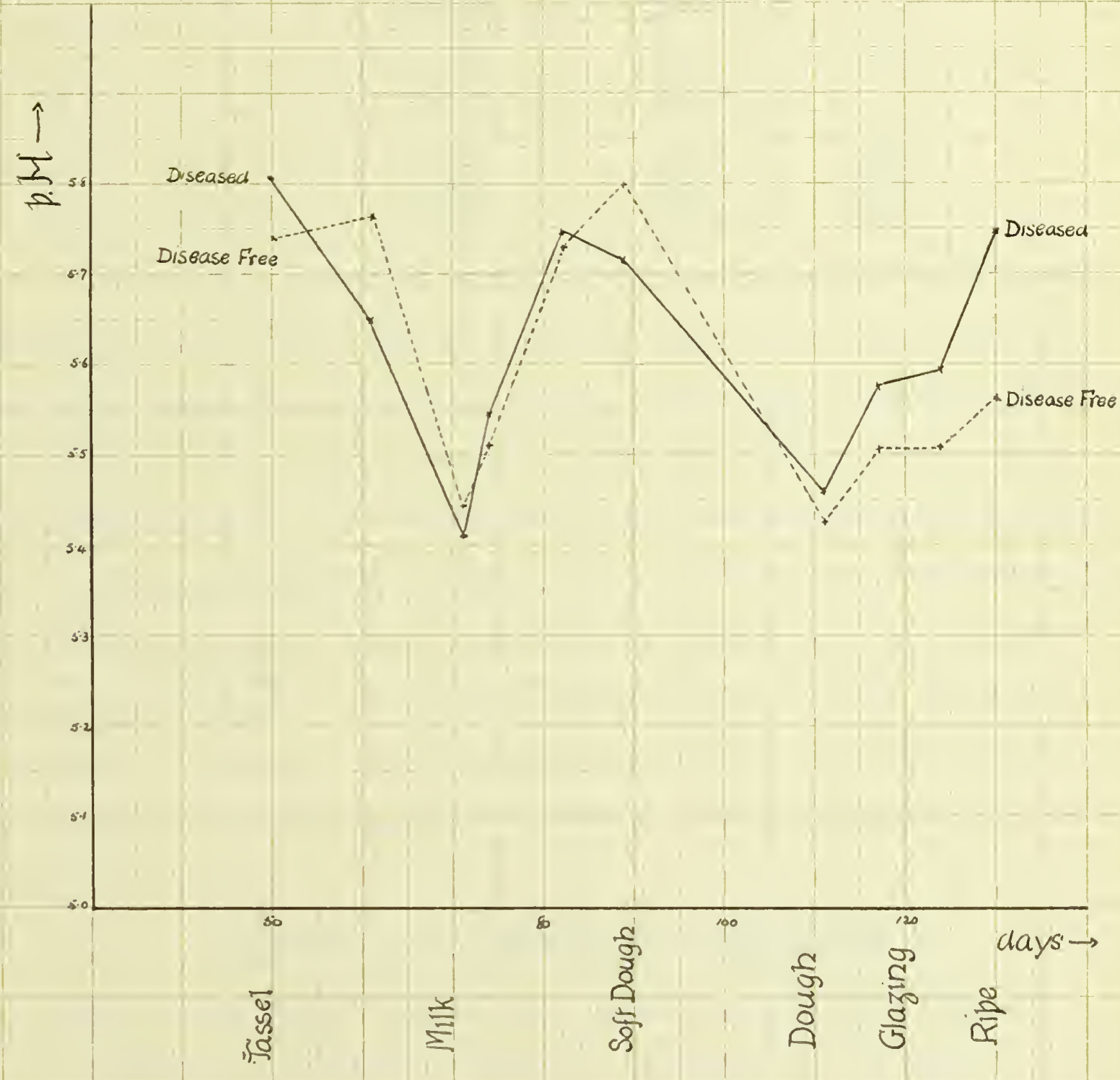



Relation Between the Hydrcgen-1on Concentration of the Stem and Lower Node

Table 3.

\begin{tabular}{|c|c|c|c|c|}
\hline Date & Age & Root & Stem & Staze of Development \\
\hline $\begin{array}{r}\text { JuI } 7 \\
13\end{array}$ & $\begin{array}{l}50 \\
56\end{array}$ & of $\begin{array}{l}5.418 \\
5.511\end{array}$ & pI $\begin{array}{l}5.740 \\
5.816\end{array}$ & Vegetative \\
\hline Aug. $\begin{array}{l}1 \\
8 \\
\end{array}$ & $\begin{array}{l}74 \\
81\end{array}$ & $\begin{array}{l}5.308 \\
5.579\end{array}$ & $\begin{array}{l}5.511 \\
5.782\end{array}$ & Milk \\
\hline $\begin{array}{r}\text { Sept. } 8 \\
20 \\
26\end{array}$ & $\begin{array}{l}112 \\
124 \\
130\end{array}$ & $\begin{array}{l}5.308 \\
5.664 \\
5.654\end{array}$ & $\begin{array}{l}5.579 \\
5.511 \\
5.562\end{array}$ & $\begin{array}{l}\text { Dough } \\
\text { Ripe } \\
\text { Ripe }\end{array}$ \\
\hline
\end{tabular}

This table shows that unt1l meturity was reached, the roots were consistently pE.2 to pE.3 more acid than the stems. After this stage the roots becane slightly nore alkeline than the stems. These results are strikingout of line with the laboratory findings in the first part of this article, which showed that the roots of the potted plants were more alkaling than the tops. The laboratory plants, bowever, were all seedings not over twenty-el ght days old and the data for fleld condltions were obtained on very mach older plants. It is difficult to see why there should be such a maried lifference in the two sets of results. For the present we may assurue that the difference in soli conditions and growth phase are sufflclently ereat to account for such a change.

\section{Comparison of the Fydrogen-icn Concentration}

of the Julce from the lower Node of Diseased and Disease free Corn

The data in Trble 2 and Flgure 1 can be used for the purpose of this comparison. These results were obtaired from apparently sound plants grown on the unl lined soil.

A General study of ths table seems to show no sienlficent difforence between the two strains. A difference can be brought out, however, if the dough stage is taken as the dividing IIne. Before this stafie there sems to bo no marked difference in the hydrocen-ion concentration. In two cases the 

Graph 11 lustrating the rariation in hydrogen-ion concentration betweon stem and root.

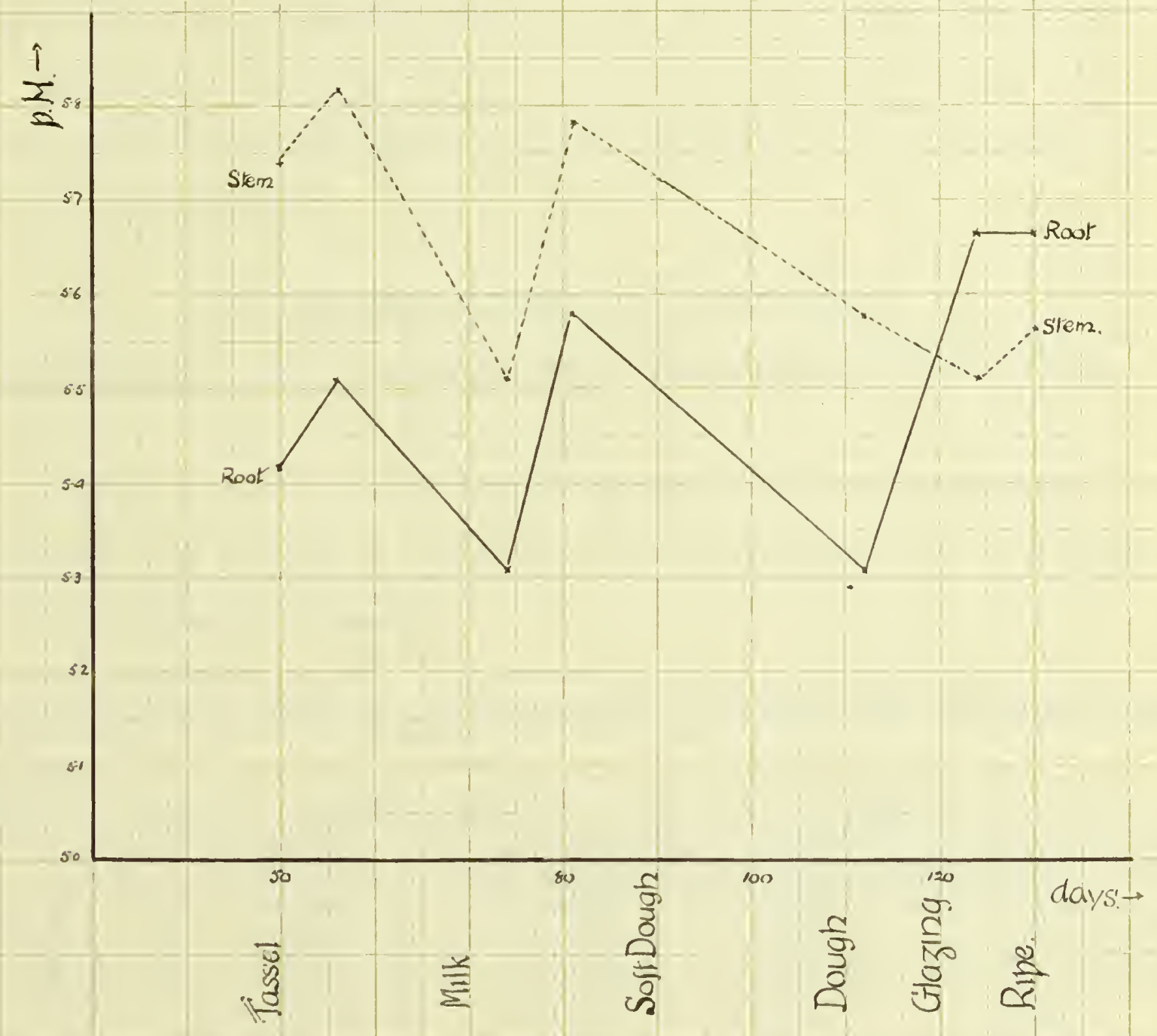



disease free corn shows the greater acldity and in three cases the reverse is tme. After the dough stage is reached, however, the d1sease free corn consistently shows a greater hydrogen-ion concentration than the diseased. This conflms Hoffer's ${ }^{11}$ work, but can be partly explained on the grownds that the diseased corn in this experiment tended to dry out more rapldiy than the disease eree. Th1s drying out, probably due to a shortening of the life cycle of the diseased plants by the pathogenes, leads to a lowering of the hydrogen-ion concentration in the season.

The Influence of Liming on the Eydrogen-1cn

Concentration of the Juice from the Lower Nodes of Diseased and DIsease Free Corn

Plants for this test ware pulled from the 1 lmed soll and compared with sinilar ones gathered at the same tire from the unimed soil. The results are giver in Table 4 and Flgure 3.

The Influence of Linling on the Hydrogen-1on Concentration of the Plant Juice Table 4.

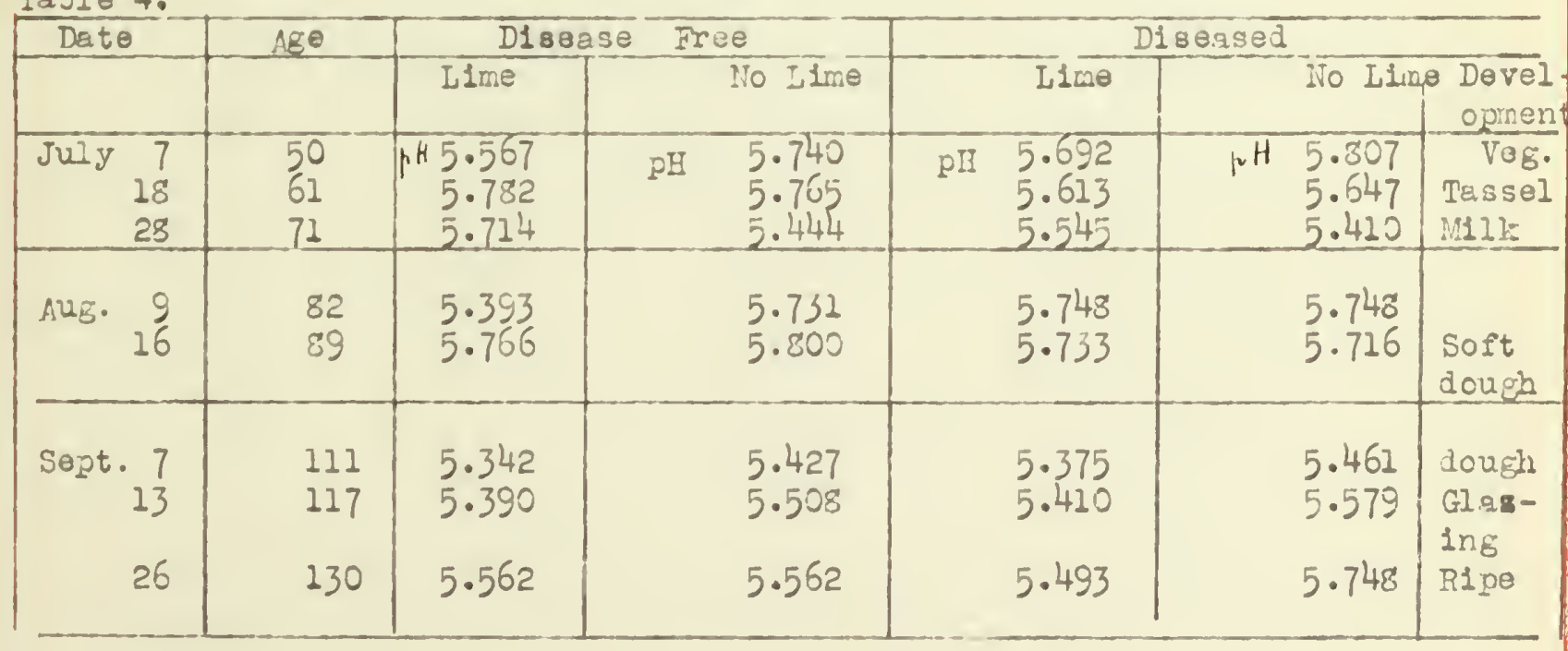



Graph 1llustrating the influence of liming on hydrogen-1on concentration.

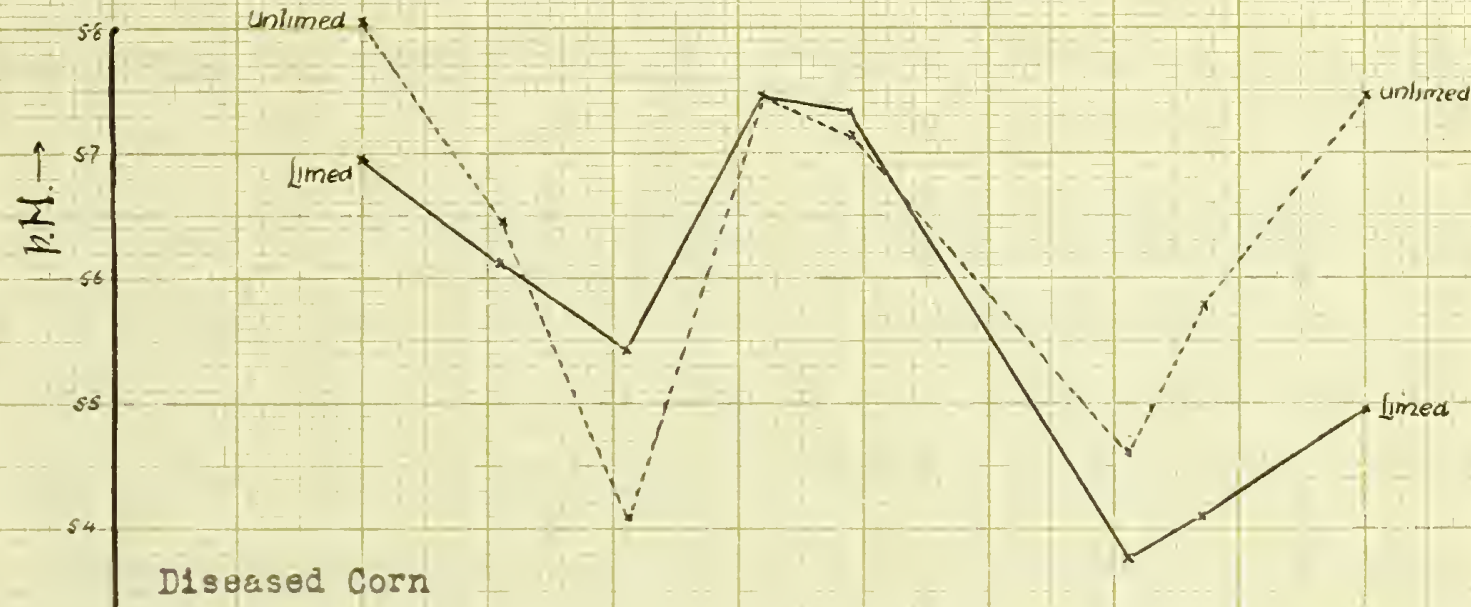

D1suased Corn

s.3
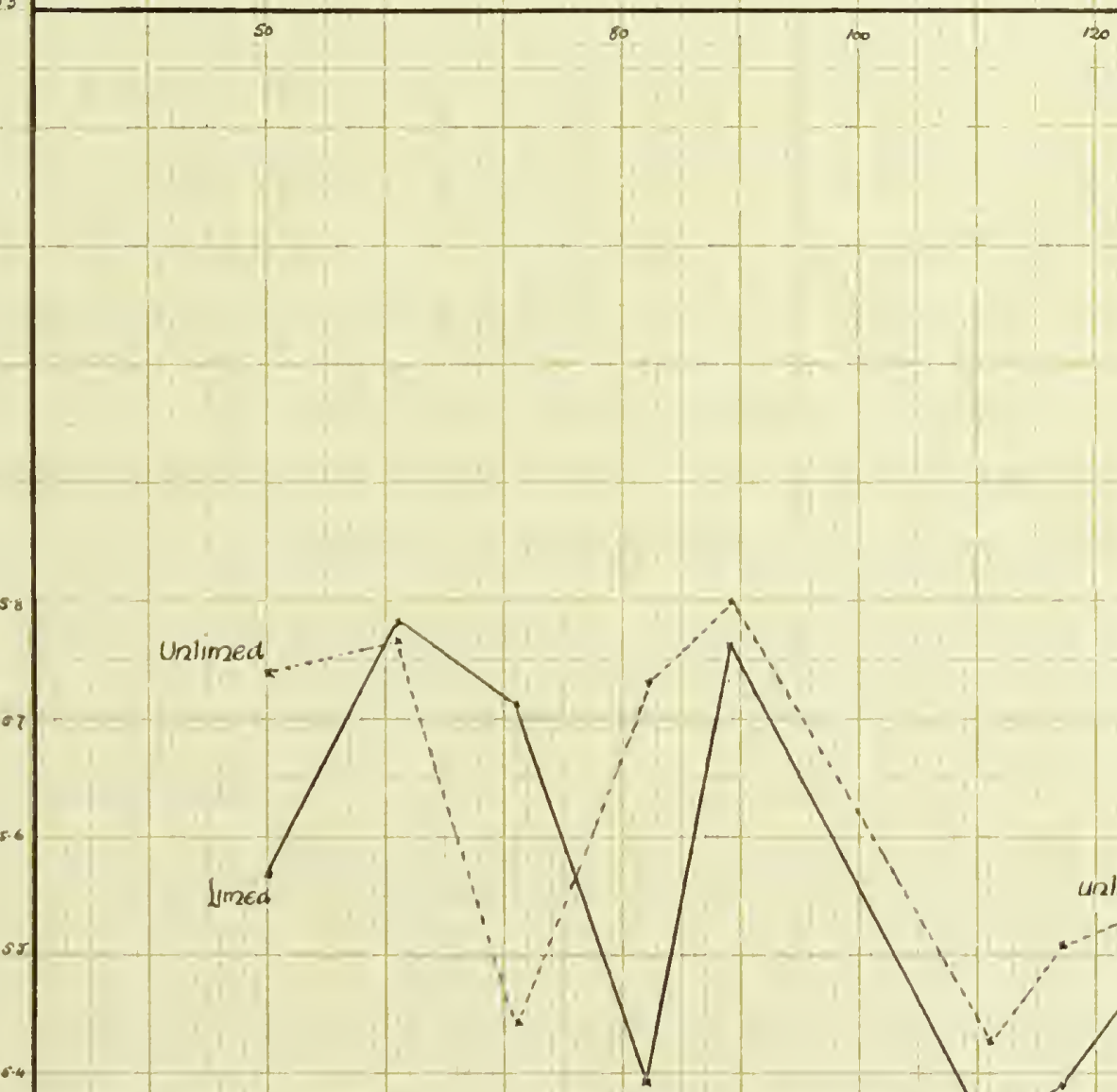

D1sease Free Corn
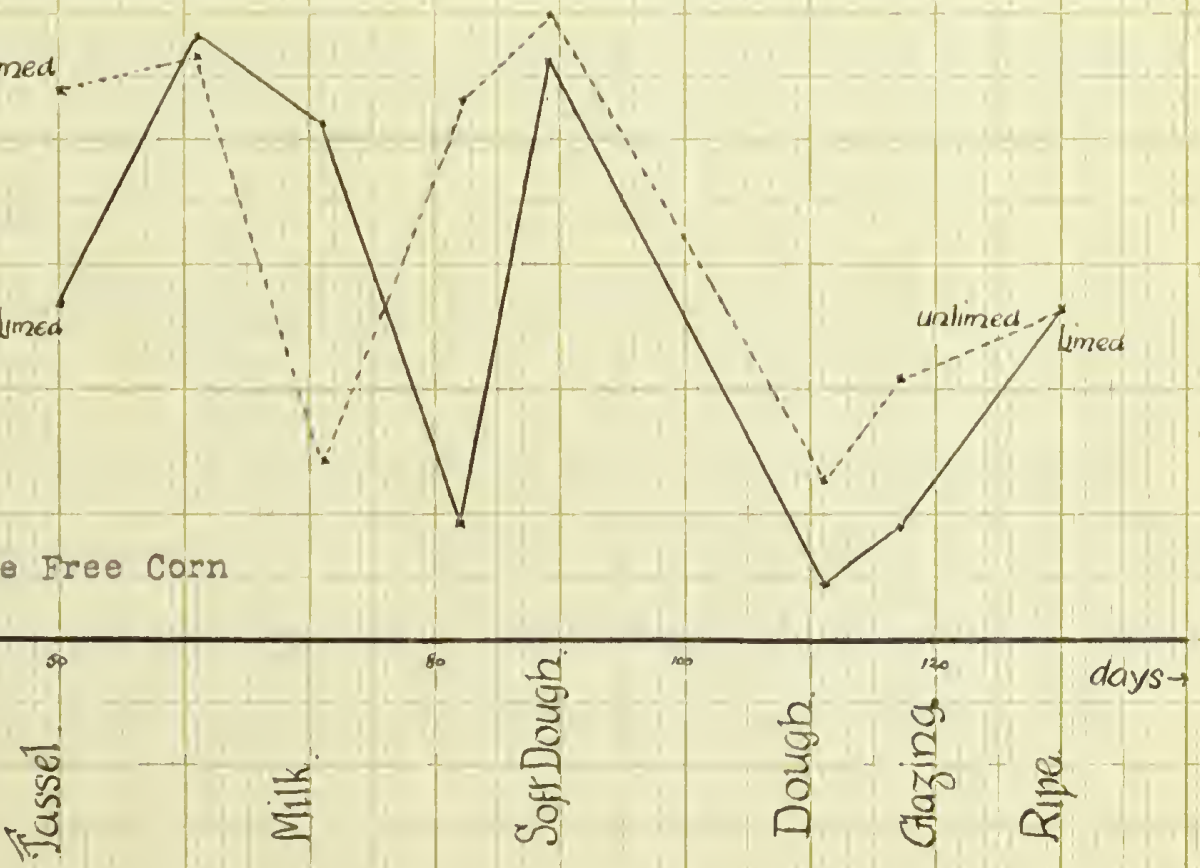



\section{$43-$}

There is too mach variation in these flgures to warrant any definite conclusions. The fact stands out, horrver, that by the end of the saason liming seems to increase the acidity of the sap in both the diseased and disease freo corn.

Instead of the lowering of acldity seen in the wnlimed plants as they mature, the hydrogen-ion concentration seems to be maintained until later in the season. This is particularly true of diseased corn. This support, if it actually occurs, may partly explain tho beneficlal effect of lining under certain condition.

inmerous pathozenes are very sensitive to pH changes in the nutrient

material in which they occur. Therefore, by sustaining the hydrogen-ion concentration of the plant fufce, liming mey render the host less susceptible to the attack of root rot organis. Whether it does this by actually increasing the hydrogen-ion concentration, or by incrasing tine vigor and therefore indirectly Increasing the kydrogen-ion concentration, wakes no difference to the final effect

So far no rarked differences in hyjrogen-ion concentration have been brought out between the diseased and disease frea corn. It was not, however, unt1l september that any obviously diseased stalks were avallable for testing purposes. Only then was it posible to see if this difference in hydrogen-1on concentration was merely a natural phenouenon or whether it was the result of pathological conditions.

To investigate this polnt apparently disease frea stalks were selected from the diseased rows on the unlimed soll and compared with stalks showing discoloration or docay in the lower nodes fran the same rows. By longitudinal sectloning these diseased stalks were arbitrarily classified into groups consistIng of 81 ghtly infected, discolored, badly infected and decayed stalks. These groups are 11lustrated by plates 6-10. Table 5 gives the pI values of the different groups. 



\section{$44-$}

The Influence of Disease on the Fydrogen-ion Con-

centration of the Plant Juice

Table 5 .

\begin{tabular}{|c|c|c|c|c|c|c|}
\hline Date & $\begin{array}{l}\text { Ago in } \\
\text { Days }\end{array}$ & $\begin{array}{l}\text { Apparently } \\
\text { Disease Free }\end{array}$ & $\begin{array}{l}\text { Slightly } \\
\text { Infected }\end{array}$ & Discolored & $\begin{array}{l}\text { Badly } \\
\text { Infected }\end{array}$ & Decayed \\
\hline Sept. 8 & 112 & PE 5.579 & $5 \cdot 782$ & & & 7.033 \\
\hline 14 & 118 & $5 \cdot 253$ & 5.337 & & 7.624 & \\
\hline 19 & 123 & 5.562 & & 5.610 & & \\
\hline 20 & 124 & 5.596 & 5.816 & 6.103 & & \\
\hline 21 & 125 & 5.562 & & $\begin{array}{l}6.728 \\
6.898 \\
\end{array}$ & & 7.253 \\
\hline 23 & 127 & 5.376 & 5.444 & & 7.878 & 6.595 \\
\hline 24 & 128 & 5.358 & & & 7.405 & 6.390 \\
\hline 27 & 131 & & 5.681 & & $\begin{array}{l}7.996 \\
7.794 \\
8.216\end{array}$ & \\
\hline 28 & 132 & & & & $\begin{array}{l}6.948 \\
8.047\end{array}$ & 7.472 \\
\hline $\mathrm{AV}$ & & $\mathrm{pH} \quad 5.470$ & 5.612 & 6.335 & 7.738 & 6.968 \\
\hline
\end{tabular}

Table 5 is open to several criticisms among which are: the arbitrary nature of the classiflcation, the mall number of readinge recorded and the large amount of variation in these readings. To some oxtent this variation may be due to mistakes which could easily be made in classifying the stelks. It is clear, however, that there is a very decided lowering of hydrogen-1 on concentration as the diseased condition develops, and a subsequent return to more or less noutrallty soon after death.

Wagner, working along simflar lines, reported the same premortal lowering of hydrogen-ion concentration in his diseased plants with what he called a "Post Mortalen Sauerung", or rotum of acldity, after death. Tho results described in Table 5 confirm his very well.

There is st1ll the possibility that a change in hydrogen-1on concentration, sinilar to the one just described, may occur in nonal stalks as they 

mature and subsequently decay. Unfortunately the slgniflcance of the last set of results was not realized or the findings plotted, until it was too late to secure any more stalks. The pH values of the juice of two almost dead and three degd disease free stalks, which vere apparently disease free, were secured, howerer, and they indicated that a decided decrease in acidity also occurs in disesse free corn as 1t dries out. In fact Haas describes a lowering of the bydrogen-1on concentration of the juice in the petals as a flower ripens, which is probably a similar phenomenon to the maturing of a corn plant.

This does not leave the matter altogether in doubt, as the change in hydrogen-ion concentration which occurs in diseased stalks shows itself before the stalks are mature. The diseased plants in Table 5 are not any more mature, when Judzed by external appoarences, than the apparently disease free plants of the same table or the rape diseased and disease free plants of Table 4.

From these resuits it seems evident that the disease brings about a decrease in the hydrogen-ion concentration of the plant juice. How it does this is not so clear. The decrease may be due to the direct activity of the pathogenes. or to a premature maturity brought about by their activities. In either case the effect is the same - the hylrogen-ion concentration of the juice is lowered before the plant 18 ready to mature in the normal fashion. 



\section{$26-$}

\section{SUTMARY}

These preliminary investigations cover only one season and the emount of data accurulated is small. Under the conditions described, however, and as far as the experiments have gone, the following conclusions can be drawn:

(1) Under mormal conditions" enviromental factors such as temperature, molsture and Ilght, do not necessarily produce any marked offect on the hydrogen-1on concentration of the plant juice.

(2) There is a progressive change in the hydrogen-1on concentration of the juice as the corn plant develops. The acidity is low to begin with, reaches a raximun about the milk or dougb stage, and subsequently declines as the plant matures.

(3) Ilning apparontly does not effect the bydrogen-ion concentration of the juice until the plant has reached the dough stage.

(4) Disease lowers the hylrogen-1on concentration of the plant juice. 

1 Beneke, W

1909. Die van der Cronesche Nahrsal zlosung, Zietschift fur Botanik, Vol. 1, p. 235-352.

2 Clark, w. Mansfleld

1920. The Determination of Eydrogen-ions.

T11liams Wilkins Company. Iiterature cited p. 124 and 192.

3 Clements, F. E.

1921. Aeration and air-content. The role of oxygen in root activity. Carnagla Institute of Kashington, publication No. 315. Literature c1ted p. 69-79.

4 Clevenger, C. B.

1919. Hydrogen-1 on Coniantration of Plant Juices.

Soll science, Vol. VIII, ivo. 3, p. $227-242$.

5 Daggar, B. I4.

1920. Eydrogen-1 on concentration and the composition of nutriant solutions in relation to the growth of seed plants.

Annal s. Mo. Bot. Gerlen. Vol. 7, p. 149.

6 Hras, A. R. C.

1920. Studies on the raaction of plant juises.

Soll Sclence, Vol. IX, No. 5, p. 341-367.

7 Ears, A. R. C.

1916. Acldity of plant colls as shown by natural indlcators.

Jour. B10. Chore. Vol. 27, p. 233-241.

3 Barvey, R. B.

1920. Relation of catalase and oxidase and hydrogen-ion concentration to the fortation of over-growth.

Amer. Jour. Bot. Vol. 7, No. 5, p. 21l-22l.

9 HI gard, E. W.

1911. Solls, their fumation, properties and composition.

Macklilan Canpany. Ilterature cited p. 209.

10 Boagland, D. R.

1919. Relation of the concentration and reaction of the nutrient medium to the growth and absorption of the plants.

Jour. Agr. Pes. Vol. XVIII, No. 2, p. 73-127.

11 Hoffer, G. I. and Carr, R. H.

1920. (1) Iron accurmation and mobllity in diseased corn stalks.

(2) Experiments to test the effects of Iron salts on corn plant 8 .

Phytopathology, Vol. 10, No. 1, p. 56-57. (Abstract) 

12 Holbert, J.R., Burlison, H. L. et alia

1922. Fariy $\nabla 1$ gor and final yiela in field corn as influenced by com root, stalk and ear rot diseases.

Professional Paper U. S. D. A. (In process of publication)

13 Eoplins, E. F.

1921. (1) Growth and germination of Gibberella saubinetti at varying hydrogen-1on concentration.

(2) Hydrozen-1on concentration of the soll and seeding infection by Gibberella saubinetti.

Phytopathology, Vol. II, No. 1, p. 36. (Abstract)

14 Jones, L. E. and Shive, J. T.

1920. Influence of Iron In the forms of Felric Phosphate and Ferrous sulphate upon the growth of wheat in a nutriant solution. Soll sclence, Vol. XI, No. 2, p. 93-98.

15 Jones, I. H. and Shive, J. W.

1921. Effect of Amoniurn Sulphate upon plants in nutrient solution supplied with Folric Phosphate and Ferrous Sulphate as sources of 1ron. Jour. Agr. Res. Vol. XXI, No. 10, p. 701.

16 Jost, Ludwh g

1906. Iectures on plant physiology. Literature c1ted p. 199. Trans. by R. J. Harvey Gibson. Oxford Univ. Prass.

17 Long, E. R.

1915. Ac1d accurralation and destruction in large succulents.

The Plant Morld, Vol. 18, 110. 10, p. 261-272.

13. McCal1, A. G. and Haas, J. R.

I920. The Hidrogen-ion concentration of cartain throe salt nutrient solutions for plants.

Soll Sclence, Vol. X, No. 6, p. $481-455$.

19 Nat1onal Researca Counc1l

1919. A plan for cooperative resoarch on the salt requiranents of representative agricuitural plants. (Edited by Burton E.

L1vingston) Sec. Edition 1919.

20 Pfoffer, W.

1897. The physiolog of plants by Dr. W. Pfeffer. Trans. by A.

T. Ewart, 2nd. Ed. Vol. 1. Ilterature c1ted p. 326, Oxford Univ. Press.

21 Portholm, L, Ritter V.

Г्र01. Uber die llotwendigeit des Kalkes fur Kelmlinge, Inberondere bel holerer Temperatur.

S1tz. Berlsh. d. k. Akad. W1ss. 1901 Wion Abt 1 p. 113-157 



\section{$49 \%$}

22 Salter, R. M. and McIlvaine, T. C.

1920. Effect of reaction of solution on germination of seeds and on the growth of seedlings.

Jour. Agr. Res. Vol. XIX, No. 2, p. 73-36.

23 Schnd dt, C. I. A. and Hoagland, D. R.

1919. Table of PQ, $\mathrm{B}$ plus and OE - values corresponding to electromot1ve forces determined in hylrogen electrode measurements, with a bibliography.

Un17. Cal11. Pab. Physiol., 5, No. 4. 23.

24 Shive, J. T.

1920. The influence of sand upon the concentration and reaction of a nutrient solution for plants.

Soil Science, Vol. IX, No. 3, p. 109-179.

25 Trua, R.

1922. The slgnificance of calciun for higher green plants. Science, N. S. Pol. LV, No. 1410, p. 1-6.

26 Truog, E. and Meacham, M. R.

1919. Soll acidity II. Its relation to acidity of the plant juice. Soll Sclence, Vol. VII, No. 6, p. 469473.

27 Valleau, W. D.

1921. (1) Res1stance as a basis of control.

(2) Selection of disease free seed as a possible means of control of corn root rot.

Phyt opathology, Vol. II, iNo. 1, p. 34-35. (Abstract)

28 Wagner, R. J.

1916. Fasserstoffionen Konzentration und Imenultat der Pflenzen.

Centbl. Bakt. Abt. 2, Vol. 44, p. 70s-719.

29 Webb, R. W.

1919. Studies in the physiology of Fungl cermination of the spores of cortain fungi in relation to hydrogen-1 on concentration.

Annals Mo. Bot. Cardan, Vol. VI, P. 201-222.

30 We18s, Freemen and Harvey, R. B.

1921. Catalase hydrogen-1 on concentration and growth in the poteto wart diseaso.

Jour. Agr. Res. Vol. XXI, No. 8, p. 589-592.

31 Miscellaneous Publications

1909. Illinols Exper. Sta. Bulletin No. 133.

1918. Indiana Exper. Sta. Bulletin (Purduo) No. 224.

1920. U. S. D. A. Farners' Bulletin No. 1176.

1920. Kentucky Exper. Sta. Bulletin No. 226.

1921. Delaware Expor. Sta. Buzletin No. 128. 

Anton Eric Romyn was born at Pretoria South Africa, July 20, 1894. He received his bigh school training in South Africa, graduating in 1910 . His undergraduate work was taken partly at the South Afrlcan Collezo and partly at the University of Toronto, from which he obtained the B.S.A. degree in 1916. He entered the University of Illinols in 1919, receiving a M.S. In Animal Husbandry in 1920. While at the University of Illinois he was for some time on the faculty as an Assistant in Animal Busbandry. 



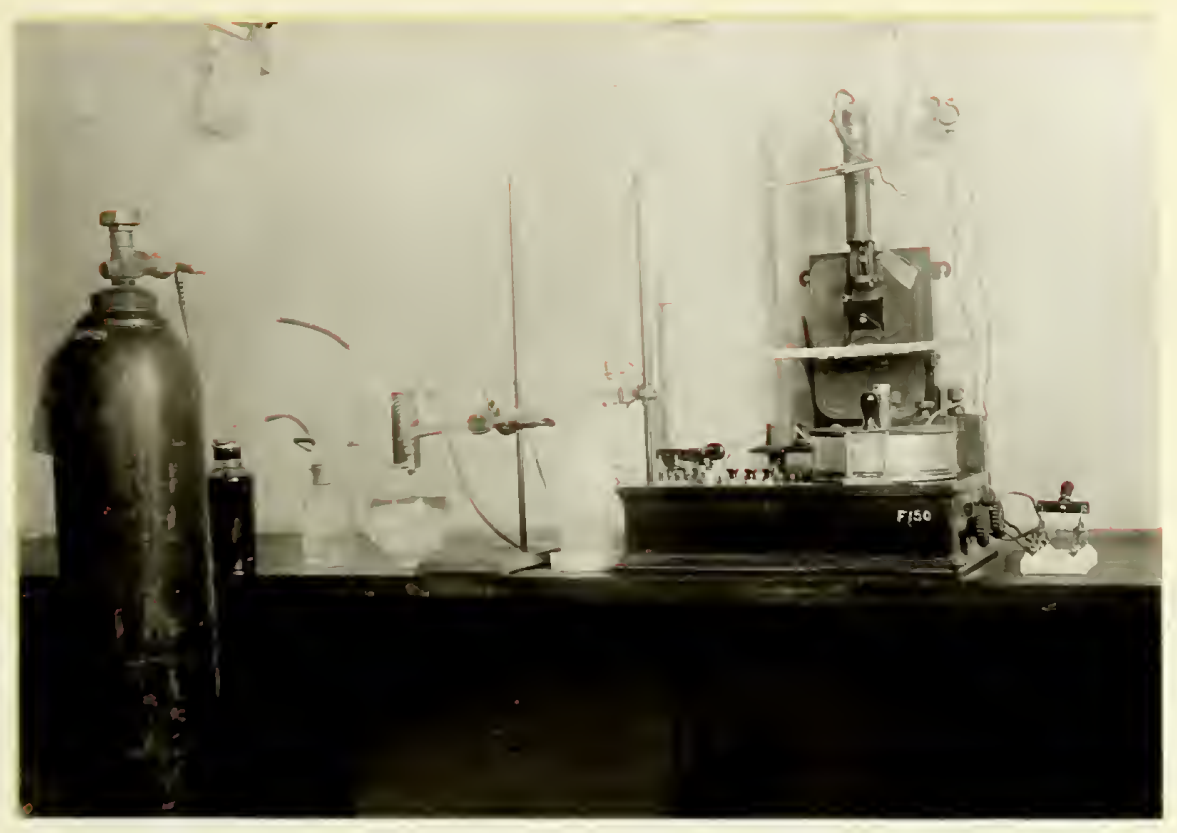

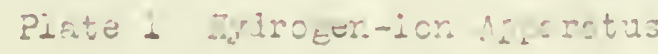

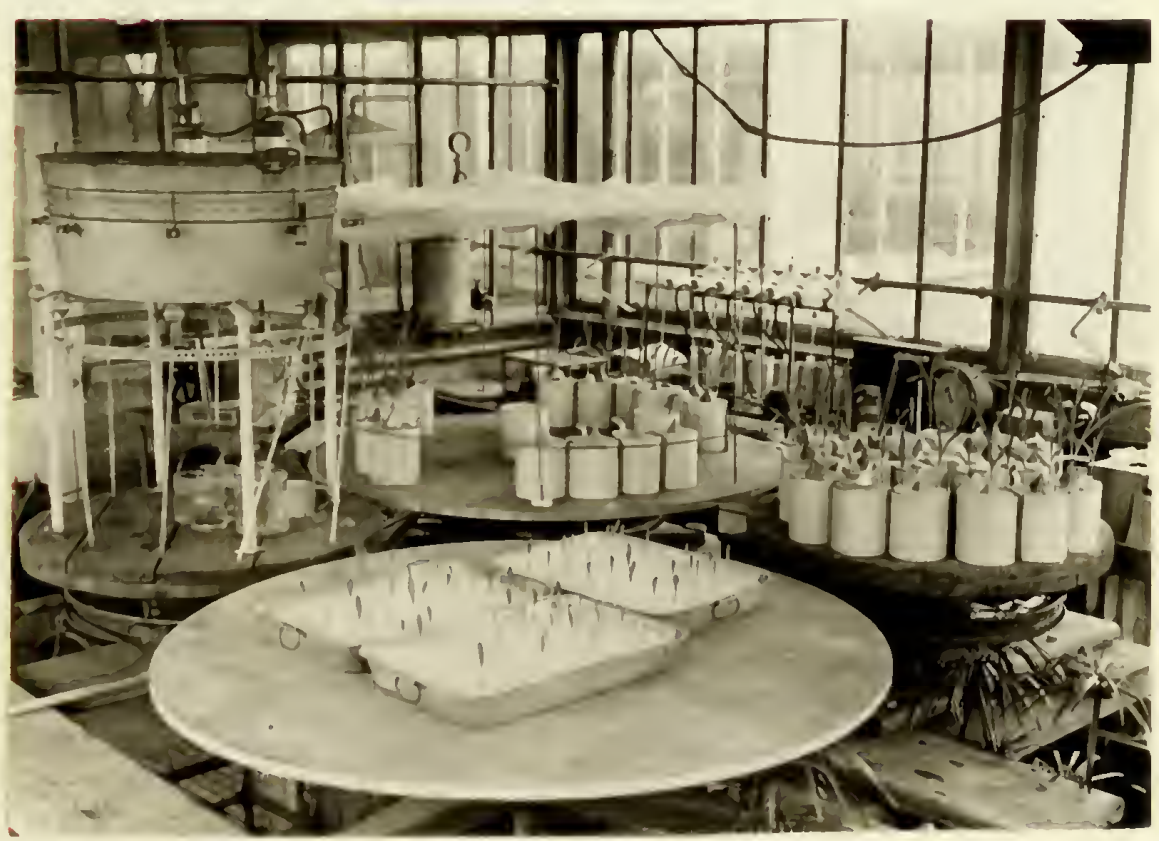





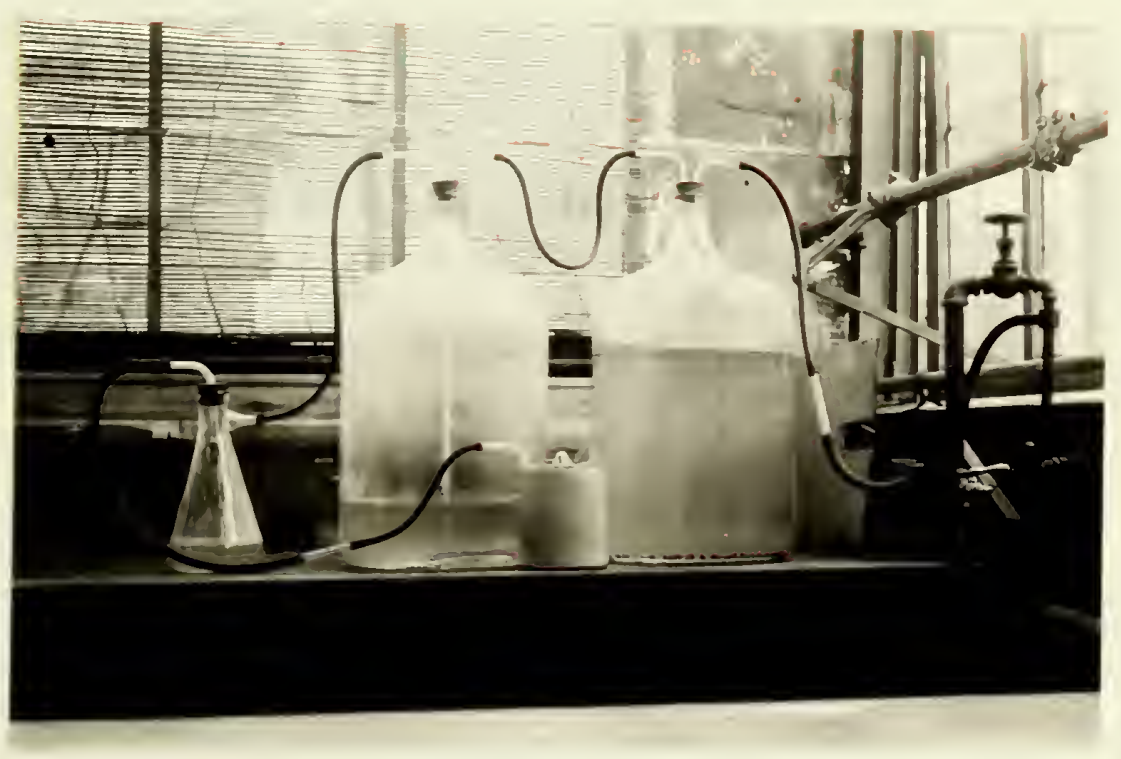

Pate 3 Aarctior iror the

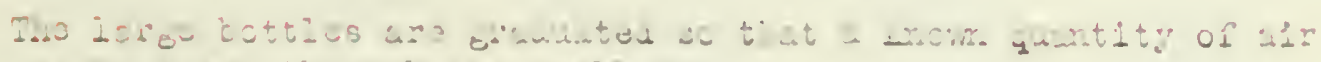

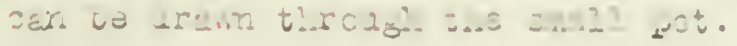





\section{Inflience o: Aeretion}

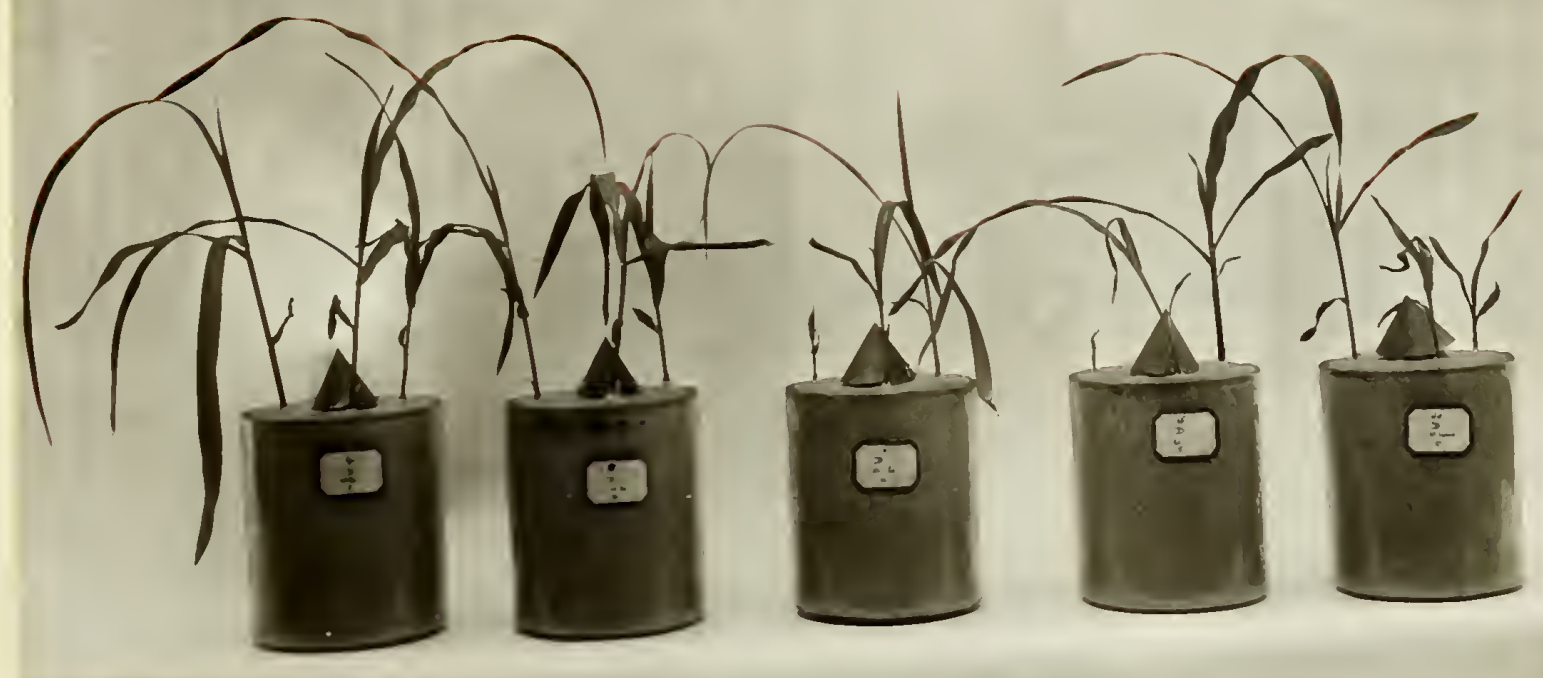

\section{Phote 4 "ilsersan" Pots}

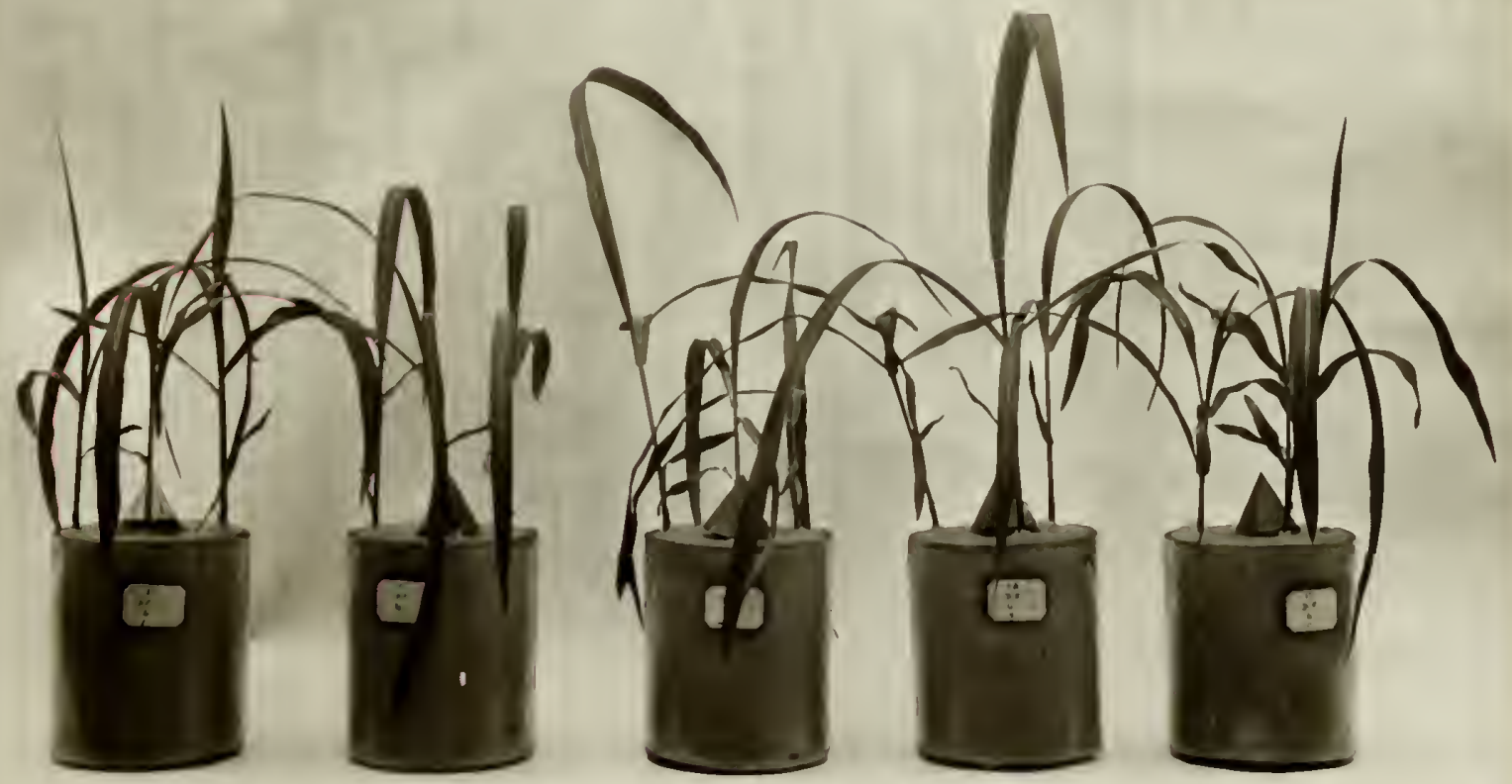





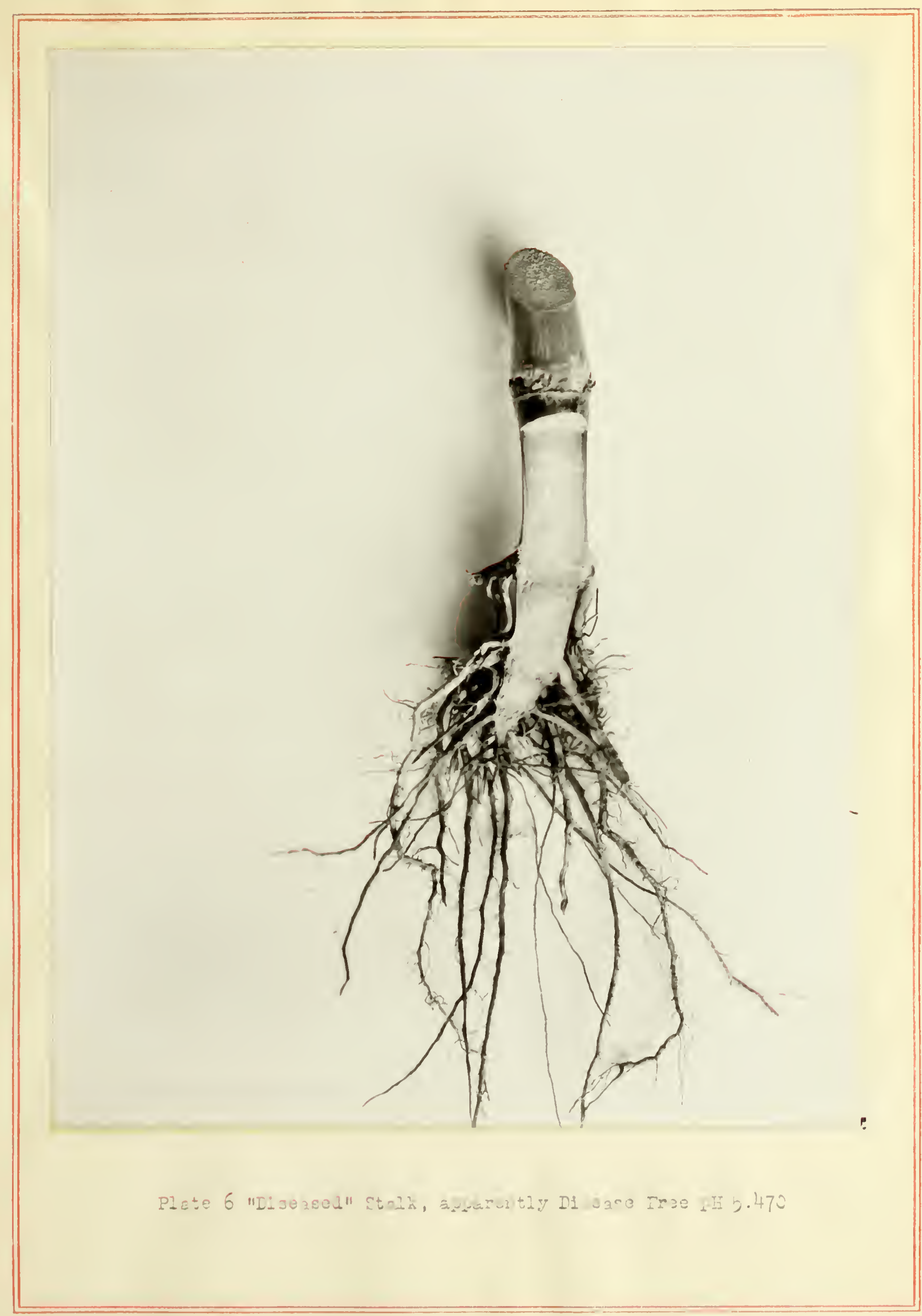





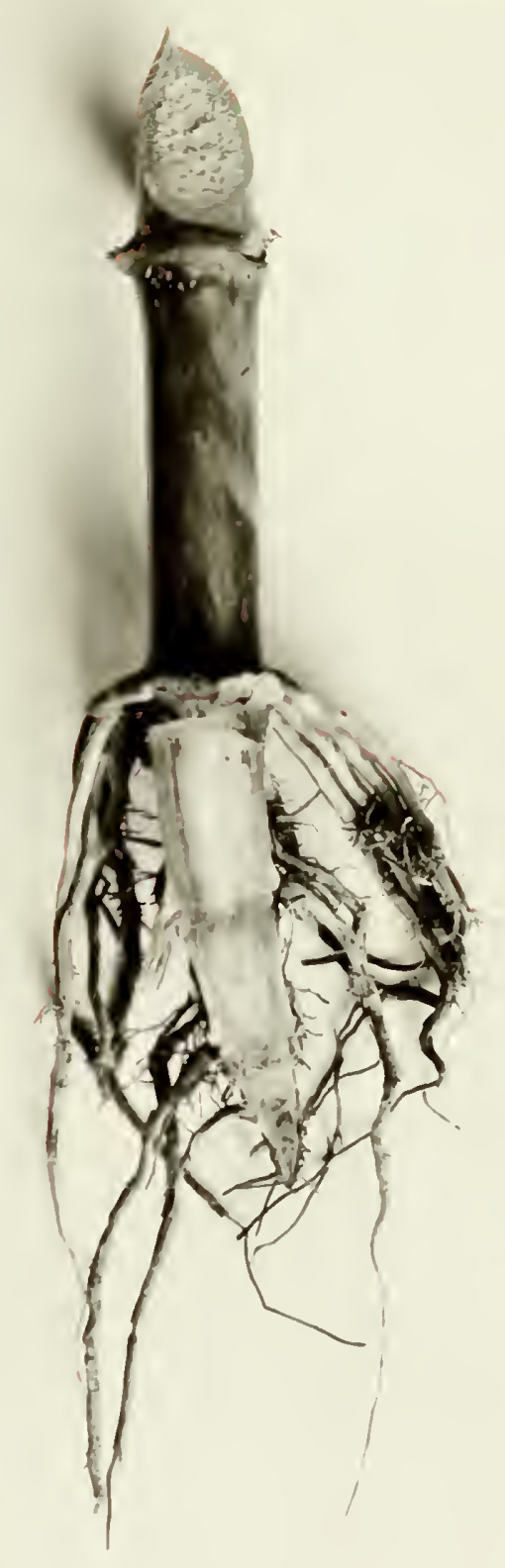





$$
1
$$





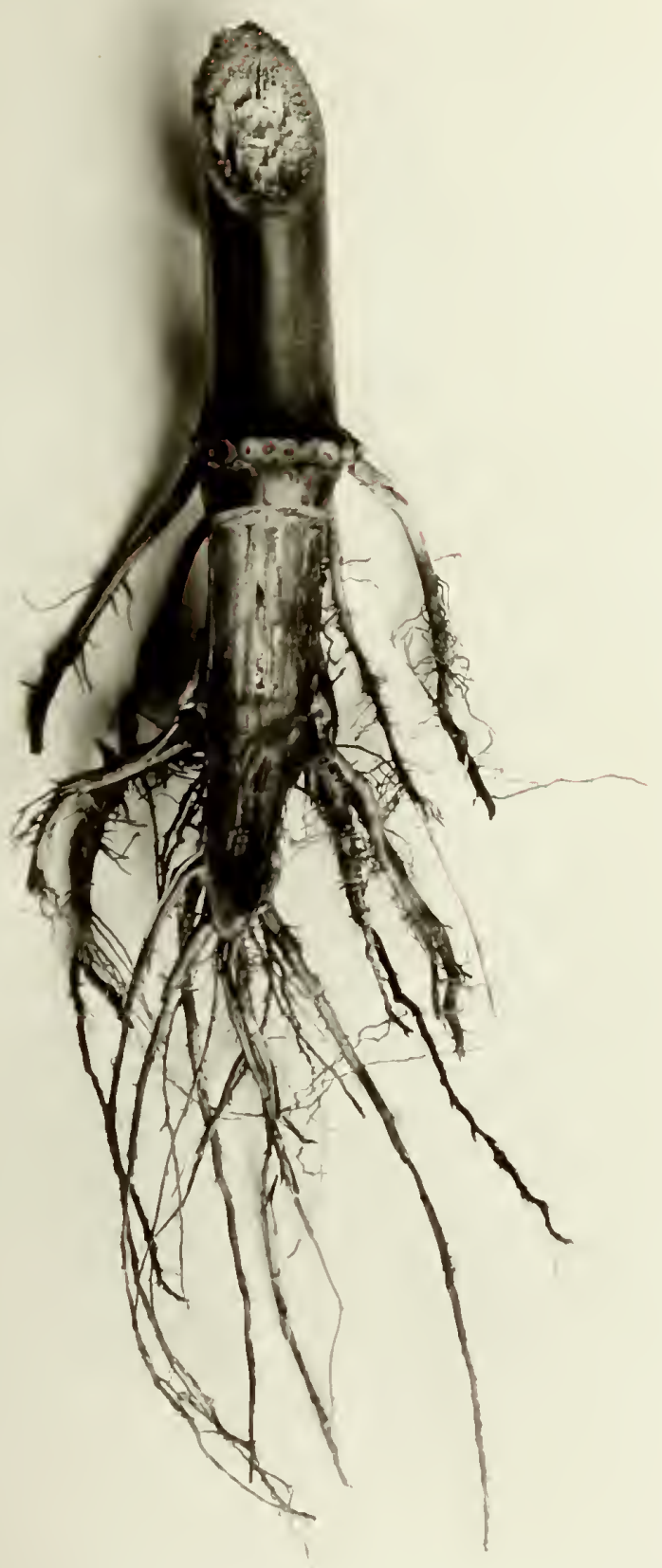





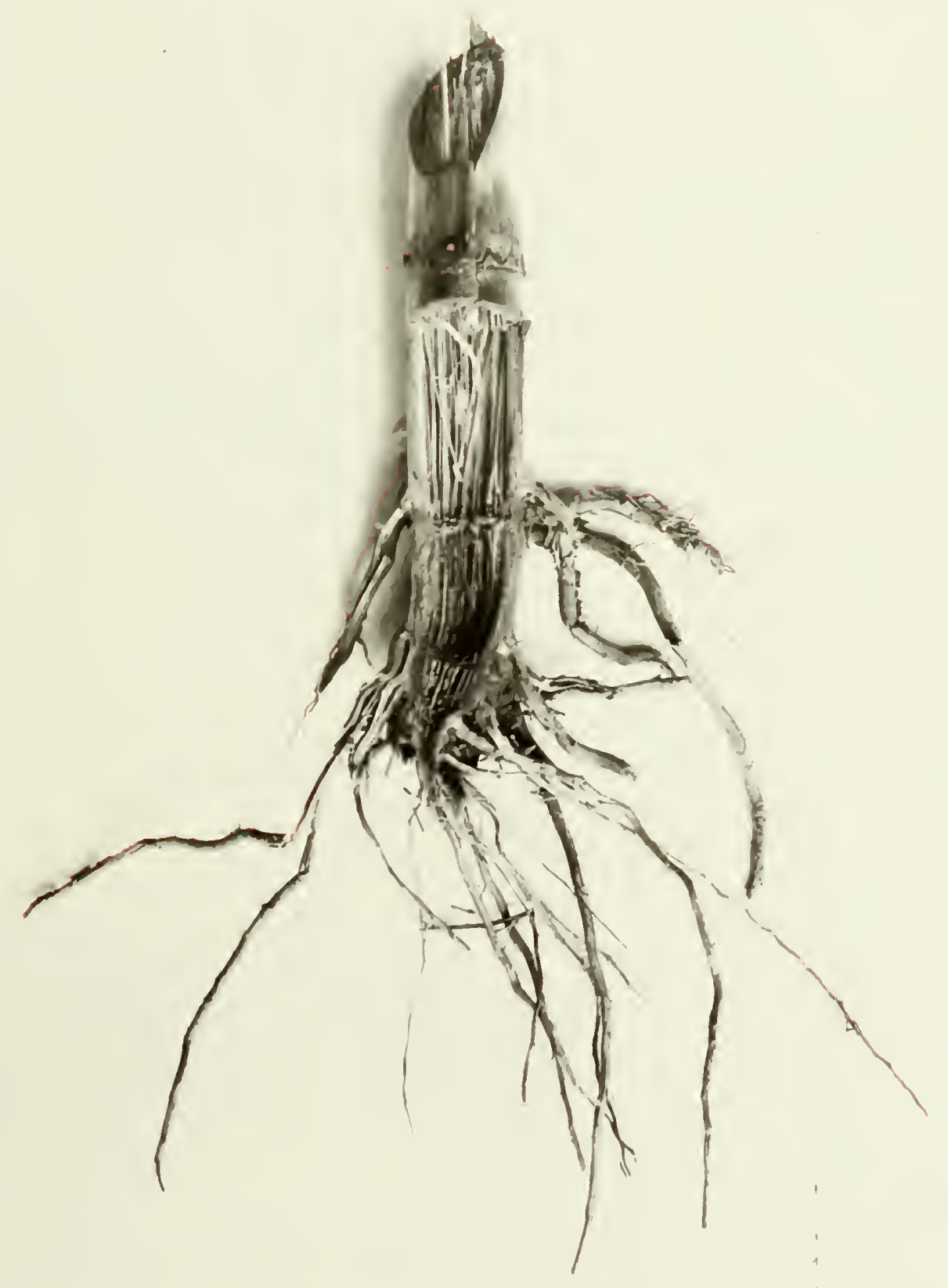

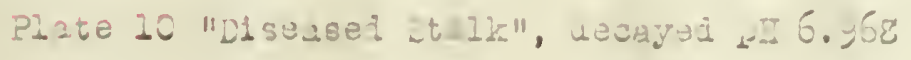


